\title{
POLÍTICAS DE CONTROL DE LA MOVILIDAD HUMANA* Las expulsiones colectivas
}

\author{
HUMAN MOBILITY CONTROL POLICIES \\ Collective expulsions
}

\section{Agostina Carla Hernández Bologna**}

\begin{abstract}
RESUMEN: En este artículo se desarrollará un análisis, delimitado al contexto europeo, sobre cómo las expulsiones colectivas representan una vulneración de derechos humanos, cuál es su impacto y cuál su tratamiento jurídico y jurisprudencial. Para ello se analizarán tres aspectos concretos: en primer lugar, el devenir de la "securitización" de las políticas de control migratorio y su externalización. En segundo lugar, se realizará un estudio de las expulsiones en general, como política de control migratorio, para analizar el caso específico de las expulsiones colectivas. Y, en tercer lugar, se analizará la política migratoria concretada a partir de la firma de convenios de readmisión de la UE o los Estados miembros con países de tránsito y origen, haciendo una breve mención al convenio bilateral firmado por España con Marruecos, con especial atención a la puesta en práctica y la regulación normativa de las devoluciones en caliente.
\end{abstract}

ABSTRACT: This article it's about an analysis on how collective expulsions represent a violation of human rights, delimited to the European context, what is their impact and what their legal and jurisprudential treatment. For that purpose, three specific aspects will be treated: first, the evolution of the "securitization" of immigration control policies and their externalization. Second, a study of expulsions in general will be carried out, as a migration control policy, to analyze the specific case of collective expulsions. And, in third place, the specific migration policy from the signing of readmission agreements of the $E U$ or the member states with countries of transit and origin will be analyzed, making a brief mention of the bilateral agreement signed by Spain with Morocco, with special attention to the implementation and legal regulation of hot returns.

PALABRAS CLAVE: expulsiones colectivas, devoluciones en caliente, políticas de control migratorio, acuerdos de readmisión, fronteras.

KEYWORDS: collective expulsions, hot returns, immigration control policies, readmission agreements, borders.

Fecha de recepción: 06/04/2020

Fecha de aceptación: 06/04/2020

doi: https://doi.org/10.20318/universitas.2020.5519

* Trabajo presentado en el I Congreso de Alumnos y Alumnas del IDHBC. Este
artículo forma parte del Trabajo de Fin de Máster: "Expulsiones colectivas. Análisis
de la sentencia del TEDH en el caso N. D. y N. T. contra España" del Máster de
Estudios Avanzados en Derechos Humanos del IDHBC.
** Becaria de la Fundación Carolina. Magíster en Estudios Avanzados en Derechos
Humanos por la Universidad Carlos III de Madrid. E-mail: agostinacarla@gmail.com 


\section{1.- INTRODUCCIÓN}

Los Estados-nación legitiman sus políticas y prácticas de control migratorio en el ejercicio de su soberanía. Sin embargo, la potestad de los Estados de regular lo relativo al ingreso y permanencia de personas migrantes en sus territorios y jurisdicciones tiene un límite en el respeto y garantía de los derechos humanos.

Los procesos de movilidad humana son históricos y contemporáneos, y responden a múltiples y diversos factores. De la misma manera, son variadas las respuestas que los diferentes Estados han aplicado a la regulación de las migraciones a lo largo de su historia. Sin embargo, la mayoría de estas respuestas están centradas en las políticas de control migratorio. En las últimos décadas, dichas políticas se han endurecido, materializándose en rechazos en frontera, expulsiones, detenciones, e incluso en el ejercicio del control migratorio más allá de la frontera territorial proceso conocido como externalización-, entre otras.

En este artículo se desarrollará un análisis, delimitado al contexto europeo, sobre cómo las expulsiones colectivas representan una vulneración de derechos humanos, cuál es su impacto y cuál su tratamiento jurídico y jurisprudencial. Para ello se analizarán tres aspectos concretos: en primer lugar, el devenir de la "securitización" de las políticas de control migratorio y su externalización. En segundo lugar, se realizará un estudio de las expulsiones en general, como política de control migratorio, para analizar el caso específico de las expulsiones colectivas. $\mathrm{Y}$, en tercer lugar, se analizará la política migratoria concretada a partir de la firma de convenios de readmisión de la UE o los Estados miembros con países de tránsito y origen, haciendo una breve mención al convenio bilateral firmado por España con Marruecos, con especial atención a la puesta en práctica y la regulación normativa de las devoluciones en caliente.

\section{2.- SECURITIZACIÓN EN LAS POLÍTICAS DE CONTROL DE LA MOVILIDAD HUMANA}

Las políticas de control de la movilidad humana, conocidas como políticas de control migratorio, son aquellas decisiones y dispositivos que diseñan e implementan los Estados-nación, a partir de su facultad soberana, para regular y controlar lo relativo a la salida, ingreso y permanencia de personas extranjeras en su territorio. En la actualidad, esos mecanismos se ejercen en múltiples espacios y bajo diversas formas.

En este estudio se utilizará el concepto de políticas migratorias para hacer referencia a diversas políticas o prácticas, nacionales 0 regionales, y que incluyen a personas en contextos de movilidad, es decir, personas solicitantes de asilo, personas refugiadas y personas 
migrantes ${ }^{1}$. A los fines de este análisis no es relevante realizar una distinción teórica entre estas categorías ${ }^{2}$. Lo que sí es necesario remarcar es que son los propios instrumentos jurídicos nacionales e internacionales los que crean y estratifican múltiples categorías de "extranjeros" 3 y son esos mismos instrumentos jurídicos los que establecen "quién tiene derecho a la protección jurídica, a los derechos y en qué medida"4. Incluso el intento de los Estados de clasificar a las personas en contexto de migración -en muchos casos, sin un procedimiento de conocimiento previo- en las distintas categorías resulta contraproducente a los fines de garantizar los derechos humanos de todas las personas, incluidas aquellas en contextos de migración ${ }^{5}$.

Si bien el control de las fronteras y los controles migratorios son parte constitutiva de la soberanía de los Estados-nación, estos deben ajustarse a las obligaciones contraídas en virtud del Derecho internacional, y específicamente respetar los derechos humanos de las personas migrantes reconocidas en normas internacionales de derechos humanos ${ }^{6}$. Es decir que el derecho de circulación de las personas puede ser objeto de regulación, y de hecho lo es, pero esa regulación no puede implicar la obstaculización total del ejercicio de ese derecho ${ }^{7}$. Sin embargo, las políticas migratorias actuales, en la mayoría de los $\operatorname{casos}^{8}$, implican, directamente, el vaciamiento del derecho de circulación ${ }^{9}$.

\footnotetext{
${ }^{1}$ S. SASSEN, ¿Perdiendo el control? La soberanía en la era de la globalización, trad. de V. Pozanco, Bellaterra, Barcelona, 2001, p. 76.

2 Para un análisis de esta cuestión Vid. P. CERIANI CERNADAS, "El lenguaje como herramienta de la política migratoria", Sur 23, vol. 13, núm. 23, 2016, pp. 97-112.

3 S. MEZZADRA y B. NEILSON, La frontera como método, trad. de V. Hendel, Traficantes de Sueños, Madrid, 2017, p. 173.

4 J. DE LUCAS, "La construcción de espacios anómicos para inmigrantes y refugiados. Sobre la creciente evolución de las políticas de la Unión Europea", Administración \& Cidadanía: Revista Da Escola Galega de Administración Pública, vol. 11, núm. 1, 2016, pp. 179-191, p. 181.

5 Oficina del Alto Comisionado de Naciones Unidas para los Derechos Humanos (OACNUDH), Migración y derechos humanos. Mejoramiento de la gobernanza basada en los derechos humanos de la migración internacional, 2013, p. 19, disponible en

https://www.ohchr.org/Documents/Issues/Migration/MigrationHR_improvingHR_Re porSPt.pdf (última consulta: 30 de enero de 2020).

6 Asamblea General de Naciones Unidas, Resolución aprobada por la Asamblea General el 20 de diciembre de 2012 [sobre la base del informe de la Tercera Comisión (A/67/457/Add.2 y Corr.1)] 67/172. Protección de los migrantes, 3 de abril de 2013, A/RES/67/172, pár. 3. b), disponible en https://undocs.org/es/A/RES/67/172 (última consulta: 30 de enero de 2020).

7 J. DE LUCAS, "Políticas migratorias sin libertad de circulación. La UE, en guerra frente a la inmigración y el asilo" en HIERRO, L. L. (coord.), Autonomía individual frente a autonomía colectiva. Derechos en conflicto, Marcial Pons, Madrid, 2014, pp. 173-192, p. 179.

${ }^{8}$ Salvo para los ciudadanos y ciudadanas ricos de países ricos. Ibídem, p. 177.

9 J. DE LUCAS, "Inmigrantes: del estado de excepción al estado de derecho", Oñati socio-legal series, vol. 1 , núm. 3, 2011, pp. 1-14, p. 5.
} 
Existen dos momentos históricos que desencadenan el recrudecimiento de las políticas migratorias. Por un lado, los procesos migratorios que se producen -e intensifican- después de la finalización de la Guerra Fría, los cuales despiertan la preocupación de la opinión pública, introduciendo en la agenda política la regulación de los llamados flujos migratorios. Por el otro, los acontecimientos del 11 de septiembre de 2001 son el hito de una lógica securitaria que se materializa tanto en los discursos políticos y mediáticos como en las políticas públicas llevadas a cabo, y que continúa hasta nuestros días ${ }^{10}$. Esta retórica de la "emergencia" viene a justificar incluso el ejercicio del control migratorio más allá de la frontera territorial.

Para legitimar este tipo de políticas de control migratorio, la producción de la "emergencia" radica en la creación de una alarma social, desde la acción política, respecto a la presencia de personas migrantes en los países de destino. Una amenaza que suele ser equiparada con la criminalidad, el terrorismo, o el narcotráfico, entre otros problemas sociales ${ }^{11}$, y que por ello logra un amplio consenso en la opinión pública. Como la inmigración, y más aún la "ilegal", representa un riesgo, una amenaza, el Estado debe intervenir para proteger a sus ciudadanos y ciudadanas. Es así como en nombre de la "seguridad nacional" se ha gestado un nuevo paradigma de control migratorio restrictivo, defensivo, securitario, que ha desplazado los derechos fundamentales de las personas migrantes ${ }^{12}$, y ha puesto en marcha todo un andamiaje de políticas y prácticas dentro y fuera de las fronteras de los Estados-nación.

De esta forma, es posible que el proceso de control migratorio comience en el país de origen, a través de la puesta en práctica del sistema de visados, que continúe en los puestos de control fronterizo y se extienda -en algunos casos indefinidamente- en el país de destino. Es este último quien evaluará que la persona migrante "nunca" deje de cumplir los requisitos legales para su permanencia en dicho territorio, y en caso contrario, el Estado soberano aplicará las políticas necesarias para su expulsión ${ }^{13}$. Es decir, una vigilancia

10 J. C. VELASCO, "Fronteras abiertas, derechos humanos y justicia global", Arbor: Ciencia, Pensamiento y Cultura, vol. 188, núm. 755, 2012, pp. 457-473, pp. 460461.

11 J. DE LUCAS, Puertas que se cierran. Europa como fortaleza, Icaria, Barcelona, 1996, p. 19.

12 A. VOGEL, "La criminalización de la migración ilegal en Estados Unidos: el caso de la ley de Arizona (SB 1070) y su parcial inconstitucionalidad" en L. L. HIERRO (coord.), Autonomía individual frente a autonomía colectiva. Derechos en conflicto, Marcial Pons, Madrid, 2014, pp. 220-255, pp. 225-227.

13 F. BARRERA LÓPEZ, La política de admisión de extranjeros inmigrantes en el derecho español y sus repercusiones ético-políticas. Una expresión de la cultura del control y de la lógica del pragmatismo, Editorial de la Universidad de Granada, Granada, 2008, p. 42. 
eterna que va más allá del momento de la admisión y la entrada en el territorio ${ }^{14}$.

El sistema de visados es, hoy en día, una pieza clave de las políticas migratorias ${ }^{15}$. Este proceso implica una de las políticas de externalización del control migratorio, ya que "transfiere el rechazo lejos del territorio del Estado"16. Es así como el ejercicio del derecho de salida, reconocido en la Declaración Universal de Derechos Humanos (en adelante, DUDH) ${ }^{17}$, encuentra su primer límite. El sistema de visados es un proceso selectivo de la migración que permite crear un perfil de "migrantes deseados" en función de las necesidades socioeconómicas del Estado de destino ${ }^{18}$.

Además del ejercicio del control migratorio en origen a través de los visados, muchos de los países receptores de migrantes ponen en práctica un sistema de control más allá de su propio territorio y jurisdicción. En estos casos, la llamada externalización del control migratorio tiene varios objetivos y se destaca por: la obligación a empresas de transporte de realizar un control migratorio, cuyo incumplimiento deriva en la imposición de elevadas sanciones pecuniarias o incluso la persecución penal por el delito de tráfico de personas; los controles de fuerzas de seguridad en aguas internacionales y en jurisdicciones de otros países; la creación de agencias y planes de control extraterritorial con sofisticados equipamientos de control $^{19}$, y hasta la creación de centros de detención de personas migrantes en países de tránsito ${ }^{20}$.

${ }^{14}$ A. PÉREZ CARAMÉS, "La evolución reciente de las políticas de control migratorio en España" en A. IZQUIERDO y W. A. CORNELIUS (eds.), Políticas de control migratorio. Estudio comparado de España y EE.UU., Bellaterra, Barcelona, 2012, pp. 143-211, p. 153.

${ }^{15}$ C. WIHTOL DE WENDEN, ¿Hay que abrir las fronteras?, trad. de J. M. Marcén, Bellaterra, Barcelona, 2000, p. 43.

${ }^{16}$ A. PÉREZ CARAMÉS, "La evolución reciente de las políticas de control migratorio en España", cit., p. 166.

17 "Artículo 13.2. Toda persona tiene derecho a salir de cualquier país, incluso del propio, y a regresar a su país". Declaración Universal de Derechos Humanos, proclamada por la Asamblea General de las Naciones Unidas en su resolución 217 A (III), el 10 de diciembre de 1948 en París, disponible en https://www.un.org/es/universal-declaration-human-rights/ (última consulta: 30 de enero de 2020).

18 A. PÉREZ CARAMÉS, "La evolución reciente de las políticas de control migratorio en España", cit., p. 166.

19 Véase, por ejemplo, en el caso de Europa, la agencia de control de fronteras FRONXTEX- y sus operativos de control Tritón (Italia), Poseidón (Grecia), SophiaEUNAVFOR Med (costas de Libia). Vid. M. AKKERMAN, "Guerras de frontera. Los fabricantes y vendedores de armas que se benefician de la tragedia de los refugiados en Europa" en M. MESA (coord.), Seguridad internacional y democracia: guerras, militarización y fronteras. Anuario CEIPAZ 2016-2017, CEIPAZ y Fundación Cultura de Paz, Madrid, 2017, pp. 79-108. También es importante destacar el caso del acuerdo firmado entre Estados Unidos y México y los países de Centroamérica, conocido como Iniciativa Mérida (o Plan Mérida). Vid. M. MESA, "El tráfico de personas en el Triángulo Norte en Centroamérica: un negocio muy lucrativo" en M. MESA (coord.), Seguridad internacional y democracia: guerras, militarización y 
La obligación de las empresas de transporte de gestionar una política de control migratorio a sus pasajeros, bajo pena de sanción, refleja una de las caras de la privatización del control migratorio. Las compañías de transporte deben garantizar que las personas que viajan en sus flotas poseen la documentación legal requerida por el país de destino, y en caso contrario, y tras producirse la denegación de entrada por parte del Estado receptor, será la empresa quien se haga cargo de los costos relativos a la devolución de la persona rechazada a su país de origen. Este procedimiento implica la desprotección de los derechos de las personas migrantes, quienes verán cercenado su derecho a la circulación no por una decisión de un Estado, sino por la decisión de una empresa, que ante cualquier mínima duda, y temiendo las sanciones y costos económicos, negará el acceso a la persona migrante ${ }^{21}$.

En el caso de la Unión Europea es preciso destacar que estos aspectos están regulados en el artículo 26 del Convenio de aplicación del Acuerdo de Schengen ${ }^{22}$ y en varias directivas. La Directiva

fronteras. Anuario CEIPAZ 2016-2017, CEIPAZ y Fundación Cultura de Paz, Madrid, 2017, pp. 109-127.

20 Son los casos emblemáticos de México en América Latina y de Libia y Marruecos en África. Es de destacar que estos países se han convertido también en países de destino. Vid. Comisión Interamericana de Derechos Humanos, Derechos humanos de los migrantes y otras personas en el contexto de la movilidad humana en México, 30 de diciembre de 2013, OEA/Ser.L/V/II. Doc. 48/13, pár. 20, disponible en http://www.oas.org/es/cidh/migrantes/docs/pdf/Informe-Migrantes-Mexico2013.pdf (última consulta: 30 de enero de 2020); Consejo de Derechos Humanos de la Asamblea General de Naciones Unidas, Informe del Alto Comisionado de las Naciones Unidas para los Derechos Humanos sobre la situación de los derechos humanos en Libia y las necesidades conexas de asistencia técnica y fomento de la capacidad del país, 12 de enero de 2015, A/HRC/28/51, pár. 33, disponible en https://undocs.org/es/A/HRC/28/51 (última consulta: 30 de enero de 2020); Comisión Española de Ayuda al Refugiado (CEAR), Marruecos: Desprotección y vulneración de derechos de las personas migrantes y refugiadas a las puertas de Europa, 2015, disponible en https://www.cear.es/wpcontent/uploads/2016/11/informe_marruecos_cear_2015_definitivo.pdf (última consulta: 30 de enero de 2020).

${ }^{21}$ A. PÉREZ CARAMÉS, "La evolución reciente de las políticas de control migratorio en España", cit., pp. 173-174.

22 "Artículo 26: 1 a) Si se negara la entrada en el territorio de una Parte contratante a un extranjero, el transportista que lo hubiere llevado a la frontera exterior por vía aérea, marítima o terrestre estará obligado a hacerse cargo de él inmediatamente. A petición de las autoridades de vigilancia de fronteras, deberá llevar al extranjero al tercer Estado que hubiere expedido el documento de viaje con que hubiere viajado o a cualquier otro tercer Estado donde se garantice su admisión. b) El transportista estará obligado a tomar todas las medidas necesarias para cerciorarse de que el extranjero transportado por vía aérea o marítima tenga en su poder los documentos de viaje exigidos para entrar en el territorio de las Partes contratantes. 2. (...) las Partes contratantes se comprometen a establecer sanciones contra los transportistas que, por vía aérea o marítima, transporten, desde un tercer Estado hasta el territorio de las Partes contratantes, a extranjeros que no estén en posesión de los documentos de viaje exigidos". Acuerdo de Schengen - Convenio de aplicación del Acuerdo de Schengen de 14 de junio de 1985 entre los Gobiernos de los Estados de la Unión Económica Benelux, de la República Federal de Alemania y 
2001/51/CE de 2001 establece las obligaciones y las sanciones para transportistas que trasladan a extranjeros al territorio de los Estados miembros de la Unión Europea a los que se les ha denegado la entrada23; la Directiva 2004/82/CE de 2004 insta a los transportistas a comunicar la información de las personas transportadas 24 y la Directiva 2002/90/CE de 2002 establece las sanciones a particulares que ayuden a la entrada, a la circulación y a la estancia de irregulares. Si bien los argumentos de esta última Directiva parecieran ir encaminados a la "lucha contra las redes de tráfico", estableciéndose que no se aplicará dicha sanción "en los casos en que el objetivo de esta conducta sea prestar ayuda humanitaria a la persona de que se trate"25, son de público conocimiento los casos de sanciones penales a personas y organizaciones de la sociedad civil que colaboran, y en muchos casos rescatan, a las personas migrantes que intentan llega a Europa ${ }^{26}$. Como consecuencia de estas prácticas,

de la República Francesa relativo a la supresión gradual de los controles en las fronteras comunes, 22 de septiembre de 2000, disponible en https://eurlex.europa.eu/legal-content/ES/ALL/?uri=CELEX\%3A42000A0922\%2802\%29

(última consulta: 30 de enero de 2020).

23 Directiva 2001/51/CE del Consejo, de 28 de junio de 2001, por la que se completan las disposiciones del artículo 26 del Convenio de aplicación del Acuerdo de Schengen de 14 de junio de 1985, disponible en https://www.boe.es/doue/2001/187/L00045-00046.pdf (última consulta: 30 de enero de 2020).

${ }^{24}$ Directiva 2004/82/CE del Consejo, de 29 de abril de 2004, sobre la obligación de los transportistas de comunicar los datos de las personas transportadas, disponible en https://www.boe.es/doue/2004/261/L00024-00027.pdf (última consulta: 30 de enero de 2020).

25 Directiva 2002/90/CE del Consejo, de 28 de noviembre de 2002, destinada a definir la ayuda a la entrada, a la circulación y a la estancia irregular, disponible en https://www.boe.es/doue/2002/328/L00017-00018.pdf (última consulta: 30 de enero de 2020).

${ }^{26}$ En 2018 fue de público conocimiento el caso de la capitana del barco humanitario Sea Watch, de nacionalidad alemana, Carola Rackete, quien fue detenida por haber desembarcado en Italia con personas migrantes sin la "correspondida autorización". De acuerdo con el informe realizado por Research Social Plataform on Migration and Asylum (ReSOMA), entre 2015 y 2019 al menos 158 personas han sido investigadas por motivos incluidos en la Directiva. ReSOMA - Research Social Plataform on Migration and Asylum. VOS, Crackdown on NGOs and volunteers helping refugees and other migrants, p. 25, disponible en

http://www.resoma.eu/sites/resoma/resoma/files/policy_brief/pdf/Final\%20Synthet ic\%20Report\%20-

$\% 20$ Crackdown $\% 20$ on $\% 20$ NGOs $\% 20$ and $\% 20$ volunteers $\% 20$ helping $\% 20$ refugees $\%$ 20and\%20other\%20migrants_1.pdf (última consulta: 30 de enero de 2020). (La traducción me pertenece). En España, tuvo gran trascendencia el caso de la defensora de derechos humanos Helena Maleno, acusada del delito de tráfico de personas por sus intervenciones de alerta y rescate de personas migrantes y solicitantes de asilo en peligro en el mar. España había iniciado la investigación de acusación en 2012, la cual fue luego enviada a Marruecos, donde vive la activista. Recién en el 2018 se archivó la causa. Vid., en este sentido, la noticia de eldiario.es, G. SÁNCHEZ, "Marruecos archiva la causa contra la activista española Helena Maleno por sus llamadas a Salvamento Marítimo", eldiario.es, 11 de marzo de 2019, disponible en https://www.eldiario.es/desalambre/Marruecos-activista- 
las personas migrantes optan por vías irregulares, y más peligrosas, de migración ${ }^{27}$.

Además, muchos de los "países centrales", que son países de destino de la migración, encomiendan a países de origen o tránsito la tarea de cerrar las vías de comunicación entre países emisores y receptores. Como contrapartida a su labor, estos "países tapones"28 reciben ayudas al desarrollo 0 se entablan con ellos relaciones comerciales privilegiadas $^{29}$. Los ejemplos más emblemáticos de estos "Estados tapón" son Marruecos, Libia, Turquía y México.

La función que cumplen estos países es el distanciamiento del control migratorio de la demarcación fronteriza de los países de destino cercanos a ellos, y a partir de ahí, el intento de reducir debido a las dificultades- la inmigración que podría llegar a los países de destino. Las consecuencias de este tipo de políticas de control son, por un lado, que los países de tránsito están deviniendo en países de destino; y por el otro lado, y al igual que lo que sucede con las controles de empresas transportistas, que las personas migrantes recurren a rutas $y$ estrategias migratorias más peligrosas $y$ encarecidas ${ }^{30}$.

Es relevante destacar que muchos de esos países con los que se realizan "acuerdos de cooperación" no destacan precisamente por sus sistemas de protección de derechos fundamentales. De hecho, así lo ha expresado el Relator Especial sobre los derechos humanos de los migrantes, a quien le preocupa que en la negociación y conclusión de esos acuerdos no esté en consideración el respeto por los derechos humanos ${ }^{31}$. El tema de los acuerdos de cooperación y readmisión será desarrollado en el último punto de este artículo.

espanola-Helena-Maleno_0_876312784.html (última consulta: 30 de enero de 2020). Estos casos, como muchos otros, son el reflejo de la "criminalización de la asistencia humanitaria".

27 I. RUIZ-GIMÉNEZ ARRIETA, "Derechos Humanos: Género e Inmigración", XXXVI Congreso de Teología, Migrantes, refugiados y fronteras. De la exclusión a la hospitalidad, Centro Evangelio y Liberación, 2016, pp. 19-36, p. 12.

28 En el caso de la Unión Europea, de acuerdo con Amnistía Internacional, "la UE y sus Estados miembros prestan apoyo a los sistemas de control de la migración de países vecinos a fin de cortar el paso a los migrantes y refugiados antes incluso de que lleguen a las verdaderas fronteras de Europa. Por medio de acuerdos de cooperación con terceros países como Libia, Marruecos, Turquía y Ucrania se está intentando cada vez más convertir estos países en zonas de contención en torno a las fronteras de las UE". Amnistía Internacional, El coste humano de la fortaleza europea. Violaciones de derechos humanos en las fronteras de Europa contra personas migrantes $y$ refugiadas, 2014, p. 13, disponible en https://www.amnesty.org/download/Documents/8000/eur050012014es.pdf (última consulta: 30 de enero de 2020).

29 J. C. VELASCO, "Fronteras abiertas, derechos humanos y justicia global", cit., p. 461.

30 A. PÉREZ CARAMÉS, "La evolución reciente de las políticas de control migratorio en España", cit., p. 204.

31 "Parece que se han concertado acuerdos de readmisión con terceros países a pesar de que carecían de un sistema de asilo con un buen funcionamiento o de los recursos o la infraestructura necesarios para gestionar grandes flujos de llegada de 
En resumen, y como se ha explicado, la puesta en marcha de la externalización del control migratorio consiste, principalmente, en la "deslocalización de las fronteras"32 y en la implicancia de terceros países para controlar y gestionar los flujos migratorios.

La aplicación de los diversos mecanismos de control, con una lógica más cercana a la seguridad que a la protección de derechos humanos, ha tenido como principal consecuencia el incremento de la migración por vías irregulares. Los efectos que genera el desarrollo de una migración irregular se evidencian en el aumento de personas que mueren en el tránsito migratorio debido a la peligrosidad y precariedad de las rutas clandestinas ${ }^{33}$. También han surgido fortaleciéndose a medida que las políticas migratorias son más restrictivas- grupos o redes de personas que se ocupan de facilitar y llevar a cabo esa migración. En este sentido, es necesario realizar la distinción entre tráfico de personas y trata de personas ya que se tratan de dos delitos distintos ${ }^{34}$. De acuerdo con el Protocolo contra el tráfico ilícito de migrantes por tierra, mar y aire, se entiende por tráfico ilícito de migrantes -smuggling- "la facilitación de la entrada ilegal de una persona en un Estado Parte del cual dicha persona no sea nacional o residente permanente con el fin de obtener, directa o indirectamente, un beneficio financiero u otro beneficio de orden material"35. Por su parte, para el Protocolo para prevenir, reprimir y

migrantes de una forma que pudiera garantizar la protección adecuada de los derechos humanos". Consejo de Derechos Humanos de la Asamblea General de Naciones Unidas, Informe del Relator Especial sobre los derechos humanos de los migrantes, François Crépeau. Estudio regional: administración de las fronteras periféricas de la Unión Europea y sus repercusiones sobre los derechos humanos de los migrantes, 24 de abril de 2013, A/HRC/23/46, pár. 63, disponible en https://www.acnur.org/fileadmin/Documentos/BDL/2014/9658.pdf?view=1 (última consulta: 30 de enero de 2020).

32 J. DE LUCAS, "Políticas migratorias sin libertad de circulación. La UE, en guerra frente a la inmigración y el asilo", cit., p. 189.

33 Las cifras de personas migrantes, refugiadas y solicitantes de asilo que han muerto o desaparecido en el proceso migratorio hacia un destino internacional es escalofriante. Los datos del proyecto Missing Migrants: Tracking deaths along migratory routes son los siguientes: 4.317 en 2014, 5.761 en 2015, 7.086 en 2016, 5.689 en $2017,4.544$ en 2018 y 2.822 desde el $1^{\circ}$ de enero hasta el 14 de noviembre de 2019. De las cifras totales por año, la mayor cantidad de muertes y desapariciones se producen en el Mediterráneo. Los datos son estimaciones de la Organización Internacional para las Migraciones (OIM), las autoridades nacionales y las fuentes de los medios de comunicación. International Organization for Migration (IOM), Missing migrants. Tracking deaths along migratory routes, disponible en https://missingmigrants.iom.int/ (última consulta: 30 de enero de 2020). (La traducción me pertenece).

${ }^{34}$ Vid. Á. CHUECA SANCHO, "Protección internacional frente a la trata de personas" en F. M. MARIÑO MENÉNDEZ (coord.), Un mundo sin arraigo: el Derecho Internacional de las migraciones, Catarata, Madrid, 2006, pp. 132-157.

35 Artículo 3. Protocolo contra el tráfico ilícito de migrantes por tierra, mar y aire, que complementa la Convención de las Naciones Unidas contra la Delincuencia Organizada Transnacional, adoptado por la Asamblea General de Naciones Unidas en su resolución $55 / 25$ del 15 de noviembre de 2000 , disponible en 
sancionar la trata de personas se entenderá por trata de personas trafficking- "la captación, el transporte, el traslado, la acogida o la recepción de personas, recurriendo a la amenaza o al uso de la fuerza u otras formas de coacción, al rapto, al fraude, al engaño, al abuso de poder o de una situación de vulnerabilidad o a la concesión o recepción de pagos o beneficios para obtener el consentimiento de una persona que tenga autoridad sobre otra, con fines de explotación. Esa explotación incluirá, como mínimo, la explotación de la prostitución ajena u otras formas de explotación sexual, los trabajos o servicios forzados, la esclavitud o las prácticas análogas a la esclavitud, la servidumbre o la extracción de órganos"36.

En este sentido, en algunos casos, estos grupos son auténticas redes de crimen organizado, que además de lucrarse con las necesidades de las personas en contexto de migración, cometen otro tipo de delitos ${ }^{37}$. Es decir, cuanto más restrictivas son las políticas migratorias, mayor es el negocio y los beneficios económicos para las redes de tráfico ${ }^{38}$.

https://www.unodc.org/documents/treaties/UNTOC/Publications/TOC\%20Conventio n/TOCebook-s.pdf (última consulta: 30 de enero de 2020).

${ }^{36}$ Artículo 3.a.). Protocolo para prevenir, reprimir y sancionar la trata de personas, especialmente mujeres y niños que complementa la Convención de las Naciones Unidas contra la Delincuencia Organizada Transnacional, adoptado por la Asamblea General de Naciones Unidas en su resolución 55/25 del 15 de noviembre de 2000, disponible en

https://www.unodc.org/documents/treaties/UNTOC/Publications/TOC\%20Conventio n/TOCebook-s.pdf (última consulta: 30 de enero de 2020).

37 Es menester destacar el análisis que realiza el Relator Especial sobre los derechos humanos de los migrantes, quien considera que "el tráfico ilícito no es, al menos en su origen, una práctica coercitiva, porque la persona que pretende migrar establece un contrato con el traficante. Sin embargo, las prácticas de tráfico ilícito abarcan muchas más actividades al ser cada vez más restrictivas las políticas de lucha contra la migración, exponiendo así a los migrantes a innumerables abusos, entre otros, la explotación sexual, la agresión física, la servidumbre por deudas y el abandono. En esas circunstancias, los migrantes que son objeto de este tráfico ilícito suelen acabar siendo víctimas de violaciones que no podían prever antes de prestarse a ese tráfico. Además, en determinados casos, los migrantes objetos del tráfico ilícito pueden también llegar a ser víctimas de la trata, con lo que se difumina aún más la distinción y se origina una falsa jerarquía de victimización". Consejo de Derechos Humanos de la Asamblea General de Naciones Unidas, Promoción y protección de todos los derechos humanos, civiles, políticos, económicos, sociales y culturales, incluido el derecho al desarrollo. Informe del Relator Especial sobre los derechos humanos de los migrantes, Sr. Jorge Bustamante, 25 de febrero de 2008, A/HRC/7/12, pár. 53, disponible en https://undocs.org/es/A/HRC/7/12 (última consulta: 30 de enero de 2020).

38 A. FERNÁNDEZ PÉREZ, "Estado del bienestar y contradicciones en la ordenación de los flujos migratorios" en S. TORRES BERNÁRDEZ, J. C. FERNÁNDEZ ROZAS, C. FERNÁNDEZ de CASADEVANTE ROMANÍ, J. QUEL LÓPEZ y A. G. LÓPEZ MARTÍN (coords.), El derecho internacional en el mundo multipolar del siglo XXI. Obra Homenaje al profesor Luis Ignacio Sánchez Rodríguez, Iprolex, Madrid, 2013, pp. 791-823, p. 796. 
Pero las mafias "no son el origen del problema"39 ni el único problema. De acuerdo con Ban-Ki-Moon, quien fuera secretario general de Naciones Unidas entre 2007 y 2016, si bien se necesitan leyes contra las redes de tráfico de personas, también es necesario crear y promover canales legales y seguros como la reunificación familiar o los permisos de trabajo, y así ir desmantelando los canales de migración irregulares y peligrosos ${ }^{40}$.

Tal como sostiene De Lucas, para los Estados, sin embargo, la prioridad máxima es el control y la vigilancia ${ }^{41}$, y ello se refleja en que las políticas de control, con un sesgo policial, pueden devenir incluso en políticas de defensa. Es decir, políticas con recursos militares preparadas para proteger a la sociedad del enemigo externo que las amenaza ${ }^{42}$. Por lo tanto, si ese "enemigo" requiere de una política de defensa, ¿están los Estados en guerra contra la migración? ${ }^{43}$

Las prácticas y políticas que reflejan este recrudecimiento -y su lógica securitaria- en los dispositivos de control migratorio son, principalmente, las detenciones administrativas; la aplicación del derecho penal para las infracciones migratorias; las expulsiones $-y$ especialmente las expulsiones colectivas-; el cierre de las fronteras a través de la construcción de muros, rejas, vallas y concertinas; el patrullaje policial y militar en las fronteras; los rechazos y devoluciones en la frontera; los malos tratos o torturas; los acuerdos de readmisión y reubicaciones fallidas; las redadas en lugares de trabajo, domicilios particulares y espacios públicos; y la restricción en el acceso a derechos. Como consecuencia de ello, en el derecho migratorio se refleja la existencia de limbos jurídicos, de impunidad y situaciones de anomia ${ }^{44}$, o de estado de excepción permanente ${ }^{45}$. Estos conceptos reflejan un espacio de "infraderecho" o "no derecho" para las personas migrantes a quienes se restringe el reconocimiento

39 J. DE LUCAS, Mediterráneo: El naufragio de Europa, Tirant Humanidades, Valencia, 2015, p. 140.

40 "Ban reclama a la UE medidas «para salvar vidas» en el Mediterráneo", Europapress, 27 de mayo de 2015, disponible en

https://www.europapress.es/internacional/noticia-ban-reclama-ue-medidas-salvarvidas-mediterraneo-20150527161023.html (última consulta: 30 de enero de 2020).

41 J. DE LUCAS, "Políticas migratorias sin libertad de circulación. La UE, en guerra frente a la inmigración y el asilo", cit., p. 189.

42 J. DE LUCAS, "Negar la política, negar sus sujetos y derechos (Las políticas migratorias y de asilo como emblemas de la necropolítica)", Cuadernos Electrónicos de Filosofía del Derecho, núm. 36, 2017, pp. 64-87, p. 74.

43 Vid. J. DE LUCAS, "Políticas migratorias sin libertad de circulación. La UE, en guerra frente a la inmigración y el asilo", cit.

44 Vid. J. DE LUCAS, "La construcción de espacios anómicos para inmigrantes y refugiados. Sobre la creciente evolución de las políticas de la Unión Europea", cit.

45 Vid. G. AGAMBEN, Estado de excepción. Homo sacer II, I, trad. de F. Costa e I. Costa, Adriana Hidalgo editora, Buenos Aires, 2005. 
de sus derechos en condiciones de igualdad con las personas nacionales ${ }^{46}$.

Incluso, se agudiza la situación por la completa ausencia de garantías elementales del debido proceso en el marco de estos procedimientos. Entre las violaciones a las garantías del debido proceso más recurrentes se pueden mencionar: la falta de representación legal y de traductor; la inexistencia de información detallada; la imposibilidad de recurrir administrativamente 0 judicialmente las decisiones; la ausencia de individualidad en los procesos; la falta de autoridad competente que dictamine la medida; el incumplimiento de la aplicación de los principios de proporcionalidad y motivación suficiente en las decisiones y la omisión de otros derechos fundamentales.

Esta progresiva y constante ampliación de las políticas migratorias que priorizan el control por sobre las personas entra en tensión con una perspectiva de derechos humanos amparada en principios y estándares internacionales que la protegen (principios de non refoulment, no discriminación, proporcionalidad, prohibición de la arbitrariedad, igualdad, universalidad) ${ }^{47}$. De esta manera, a la hora de evaluar estas políticas, es posible considerar que ponen en juego normas del Estado de Derecho y de la democracia ${ }^{48}$ con la excusa de afrontar la amenaza que producirían las migraciones irregulares. Es decir, la puesta en práctica de políticas de control migratorio propias de un Estado policial, más que de un Estado social de derecho, vulneran el derecho a la vida, a la igualdad y la no discriminación, a la unidad familiar, a la tutela judicial efectiva, a la seguridad jurídica, así como también el derecho al asilo y al principio de no devolución. En algunos casos, también, la aplicación de este tipo de políticas de control migratorio lleva a la violación de la "obligación de socorro ante peligro de muerte, del derecho elemental a acoger al otro que huye del peligro"49. Los derechos básicos de las personas están en juego y ello tiene como consecuencia responsabilidades jurídicas y políticas de los Estados.

Por lo tanto, este proceso de degradación de la democracia se vincula con la idea que Mbembe desarrolla como "necropolítica", y que ha sido elaborado a partir de la obra de Foucault ${ }^{50}$.

46 J. DE LUCAS, "La construcción de espacios anómicos para inmigrantes y refugiados. Sobre la creciente evolución de las políticas de la Unión Europea", cit., pp. 179 y 182.

47 S. SASSEN, ¿Perdiendo el control? La soberanía en la era de la globalización, cit., pp. 84-85.

48 J. DE LUCAS, "Negar la política, negar sus sujetos y derechos (Las políticas migratorias y de asilo como emblemas de la necropolitica)", cit., p. 74.

49 Ibídem, cit., p. 77.

50 En el libro Hay que defender la sociedad. Curso del Collège de France (19751976), Foucault desarrolla el concepto de biopolítica que da lugar a la construcción de la noción de necropolítica. Vid. M. FOUCAULT, Hay que defender..., trad. de $\mathrm{H}$. Pons, Ediciones Akal, Madrid, 2003. 
La necropolítica niega la condición de sujeto de derecho a la persona ${ }^{51}$. $\mathrm{Y}$ en este caso, las personas migrantes son construidas como sujetos sospechosos, reforzando el discurso de la seguridad, el miedo y la discriminación; o como sujetos sustituibles, precarizados o explotados a merced del mercado económico global. Es decir, que el diseño y aplicación de este tipo de políticas de control migratorio que vulneran derechos fundamentales de las personas, aun cuando se intenten legitimar en la soberanía del Estado y el orden público, pone de manifiesto "una concepción de la política en la que la vida de los otros es objeto de cálculo y por tanto carece de valor intrínseco en la medida en que no resultan rentables o dejan de serlo"52. Es la utilización del aparato jurídico-estatal para excluir y expulsar a la población ${ }^{53}$ considerada, en palabras de Bauman, como "desecho humano" 54 . O sea que las políticas de control migratorio se amparan en el Estado de Derecho para generar exclusión y vulnerar derechos ${ }^{55}$.

Por lo tanto, las lógicas que dominan las políticas de control migratorio, la policial -y hasta bélica- y la mercantil, refieren, la primera a la defensa de la seguridad y el orden público, y la segunda, a la protección de los intereses del mercado, y en particular del mercado de trabajo.

En relación con lo anterior, y de acuerdo con Ruiz-Giménez Arrieta, estas políticas de control migratorio responden a tres grandes negocios: "el negocio de la seguridad, el de la economía política de las rutas migratorias y el de la economía política de las migraciones en los países de destino"56. El primero se beneficia del discurso de la seguridad para incrementar el negocio relacionado con la industria armamentística, la vigilancia, la construcción de muros, el lucro derivado de los centros de detención ${ }^{57}$, entre otros. Por su parte, el negocio de las rutas migratorias se materializa en la proliferación de redes de tráfico de personas. La imposibilidad de migrar por rutas regulares y seguras obliga a las personas migrantes a intentar el

51 J. DE LUCAS, "Negar la política, negar sus sujetos y derechos (Las políticas migratorias y de asilo como emblemas de la necropolitica)", cit., p. 75.

52 Ibídem, p. 72.

53 Ídem.

54 Vid. Z. BAUMAN, Archipiélagos de excepciones, $1^{\circ}$ edición, trad. de A. Santos Mosquera, Katz Editores, Madrid, 2008.

55 J. DE LUCAS, "Negar la política, negar sus sujetos y derechos (Las políticas migratorias y de asilo como emblemas de la necropolitica)", cit., pp. 73-74.

56 I. RUIZ-GIMÉNEZ ARRIETA, "Derechos Humanos: Género e Inmigración", cit., p. 28.

57 En Estados Unidos, la empresa privada Geo Group le presta servicios al Servicio de Inmigración y Control de Aduanas de los Estados Unidos (U.S. Immigration and Customs Enforcement, ICE) para la gestión de centros de detención de migrantes. Vid. Á. BERMÚDEZ, "El multimillonario negocio detrás de la detención de inmigrantes en Estados Unidos", BBC, 25 de junio de 2018, disponible en https://www.bbc.com/mundo/noticias-internacional-44584922 (última consulta: 30 de enero de 2020). 
cruce de fronteras por otras más costosas, peligrosas y largas, o sea, cuanto más cerradas las fronteras, mayor será el negocio y en muchos casos la violencia. El tercer negocio es el que corresponde con el sistema capitalista y global en los países receptores de migrantes, el cual se vincula con la funcionalidad de la migración ${ }^{58}$. Es decir, los países de destino regulan la entrada y permanencia de migrantes de acuerdo a la demanda del mercado y mientras produzcan beneficios ${ }^{59}$.

En consecuencia, la falta de reconocimiento de la migración como un derecho y de las personas migrantes como sujetos titulares de derechos y obligaciones restringe un principio liberal básico de la dignidad de las personas que es el de autonomía, el del libre desarrollo de la personalidad y el de la libre elección de los planes de vida, que en estos casos está relacionado con el principio de circular libremente 60 .

Si bien en el Derecho internacional de los derechos humanos está reconocido, en sentido estricto, el derecho a salir de un país, el derecho a circular libremente $o$ el derecho a migrar, en sentido amplio, no. El derecho a circular libremente se compone de varios elementos que requieren protección y garantía jurídica. El primero es el derecho a no migrar forzadamente y supone que la emigración debe de ser una decisión producto de la libertad y autonomía, y no de un estado de necesidad. El segundo es el derecho a salir del país, el cual, pese a su reconocimiento en la DUDH, tiene en la actualidad sus condicionamientos y restricciones debido a las políticas de control migratorio en origen, como son el sistema de visados o el control de las empresas de transporte, a los que se ha referido anteriormente. Mediante la aplicación de este tipo de políticas de control y obstaculización del derecho a salir, las personas migrantes utilizan canales migratorios más peligrosos, y por ello se pone en juego el derecho a un tránsito seguro. El tercero de los elementos que conforma el derecho a circular libremente o el derecho a migrar es el derecho a ingresar a otro país y el derecho a permanecer en él de manera temporal o definitiva en condiciones de igualdad con los nacionales. ¿Cómo es posible garantizar el derecho a salir de un lugar sin garantizar el derecho a llegar y permanecer en otro?

Todos estos derechos están relacionados con la noción de autonomía, la cual está conectada directamente con la noción de dignidad. Si no se protegen estos derechos, se vulnera la dignidad de

58 I. RUIZ-GIMÉNEZ ARRIETA, "Derechos Humanos: Género e Inmigración", cit., pp. 31-32.

59 J. DE LUCAS, "Políticas migratorias sin libertad de circulación. La UE, en guerra frente a la inmigración y el asilo", cit., p. 189.

60 J. DE LUCAS, "Negar la política, negar sus sujetos y derechos (Las políticas migratorias y de asilo como emblemas de la necropolitica)", cit., p. 82 y J. DE LUCAS, "La construcción de espacios anómicos para inmigrantes y refugiados. Sobre la creciente evolución de las políticas de la Unión Europea", cit., p. 183. 
las personas ${ }^{61}$. Es menester destacar que la dignidad humana es el fundamento de los derechos humanos, que a su vez están regidos primordialmente por los principios de universalidad, igualdad y no discriminación, por lo que la limitación a cualquiera de estos principios debe ser excepcional, interpretada de manera estricta y tener un fin legítimo y proporcional62.

En la actualidad, las diversas convenciones internacionales y los derechos adquiridos de las personas migrantes, al tiempo que limitan el ejercicio de los Estados de regular las migraciones que no sean conformes a derecho, intentan ampliar la concepción sobre la garantía y protección de un derecho a la movilidad humana. Por su parte, los Tribunales tanto nacionales como internacionales cumplen un rol central en la interpretación de este tema63. Conforme con el TEDH, en el caso Hirsi Jamaa y otros contra Italia, si bien los Estados tienen derecho a ejercer su soberanía respecto a las políticas de inmigración, ello no debe suponer prácticas o políticas que vulneren sus obligaciones internacionales de protección de derechos humanos, y en este caso en particular, las obligaciones que derivan del $\mathrm{CEDH}^{64}$.

Las respuestas de las políticas de control migratorio deben ser conforme a los derechos humanos. Sin embargo, y lamentablemente, los procesos de "securitización" de las políticas migratorias están cobrando cada vez más intensidad y están permeando las distintas políticas de control migratorio. Una de esas políticas es la relacionada con la expulsión de las personas migrantes, a la que se hará referencia en el siguiente punto.

\section{3.- EXPULSIONES COLECTIVAS}

\section{1.- Definición, categorías y regulación de las expulsiones}

Uno de los dispositivos de control migratorio utilizado por los Estados para controlar las migraciones irregulares es la expulsión. Esta consiste en el traslado forzoso o involuntario de la persona migrante fuera del país en el que reside $o$ al que quiere ingresar y del cual no es nacional. Las expulsiones pueden estar reguladas como políticas públicas y a partir de ello ampararse en leyes, reglamentos o disposiciones, o pueden ser una práctica o acción de control de hecho. En ambos casos, su realización puede contrariar y vulnerar

\footnotetext{
61 J. DE LUCAS, Mediterráneo: El naufragio de Europa, cit., p. 16.

62 F. VACAS FERNÁNDEZ, El Derecho Migratorio, Internacional y Europeo, como Límite desde los Derechos Humanos a la Discrecionalidad de los Estados en Materia Migratoria, Tirant lo Blanch, Valencia, 2017, pp. 70-72.

63 S. SASSEN, ¿Perdiendo el control? La soberanía en la era de la globalización, cit., pp. 79-80.

64 TEDH, Hirsi Jamaa y otros contra Italia, del 23 de febrero de 2012, en la demanda $\mathrm{n}^{\circ}$ 27765/09, pár. 179, disponible en

http://hudoc.echr.coe.int/eng?i=001-139041 (última consulta: 30 de enero de 2020).
} 
derechos fundamentales de las personas migrantes. Por ejemplo, si bien las expulsiones deberían realizarse al país de origen o de residencia habitual de la persona migrante a la que no se le permitió residir en el país de destino, muchas expulsiones se realizan a terceros países, con las graves consecuencias en violaciones de derechos que esto acarrea.

La expulsión, como mecanismo o dispositivo de control migratorio, puede ser designada, dependiendo del Estado y el tramo de la ruta migratoria en que se produzca, bajo diferentes nombres. Las formas más convencionales de llamar a este tipo de política de control migratorio son: expulsión, deportación, extrañamiento, repatriación, retorno, readmisión, rechazo, devolución, entre otras ${ }^{65}$. Es importante destacar que muchos Estados utilizan eufemismos para referirse a políticas o prácticas que no implican la voluntariedad de las personas. Es decir, utilizan las denominaciones "retorno" 0 "repatriación", que en muchas ocasiones van seguidas de la palabra "voluntaria", invisibilizando el carácter securitario o policial que contempla la expulsión 66 .

En sentido estricto, la CDI de Naciones Unidas define a la expulsión como "un acto jurídico o un comportamiento, atribuible a un Estado, por el cual un extranjero es compelido a abandonar el territorio de ese Estado; no incluye la extradición a otro Estado, la entrega a una jurisdicción penal internacional ni la no admisión de un extranjero en un Estado"67. Formalmente, las expulsiones son procesos, administrativos y/o judiciales, que se inician para personas migrantes que no cumplen con los requisitos de residencia legal establecidos en las leyes de extranjería o de migraciones de los países de destino. Estos procesos deben ser motivados, conforme a la ley, y no deben contrariar las obligaciones contraídas en vista del Derecho internacional. Si bien se reconoce a los Estados, en el ejercicio de su soberanía, la facultad de decidir sobre las condiciones de admisión y permanencia de las personas no nacionales en sus

65 Vid. Comisión de Derecho Internacional, Asamblea General de Naciones Unidas, Segundo informe sobre la expulsión de los extranjeros, presentado por el Sr. Maurice Kamto, Relator Especial, 20 de julio de 2006, A/CN.4/573, disponible en https://www.refworld.org.es/docid/4a2cd5f22.html (última consulta: 30 de enero de 2020).

66 Consejo de Derechos Humanos de la Asamblea General de Naciones Unidas, Informe del Relator Especial sobre los derechos humanos de los migrantes, 4 de mayo de 2018, A/HRC/38/41, pár. 15 y 17 , disponible en

https://undocs.org/es/A/HRC/38/41 (última consulta: 30 de enero de 2020).

67 Comisión de Derecho Internacional de la Asamblea General de Naciones Unidas, Informe de la Comisión de Derecho Internacional $66^{\circ}$ período de sesiones, 5 de mayo al 6 de junio y 7 de julio al 8 de agosto de 2014, A/69/10, Capítulo IV: Expulsión de extranjero, pár. E. Texto del proyecto de artículos sobre la expulsión de extranjeros, artículo 2 a), p. 13, disponible en

https://www.refworld.org.es/pdfid/5915f0e84.pdf (última consulta: 30 de enero de 2020). 
respectivos territorios, estas no pueden ser arbitrarias ${ }^{68}$. Para evaluar si esos procedimientos garantizan los derechos de tutela judicial efectiva de las personas, se deberá analizar la regulación escrita y la práctica que lleve a cabo cada Estado.

En el proyecto de artículos sobre la protección de los derechos humanos de las personas expulsadas o en vías de ser expulsadas que ha redactada la CDI, se prohíben tanto las expulsiones encubiertas como las expulsiones colectivas. A las primeras, las define como "la salida forzosa de un extranjero de un Estado que resulte indirectamente de una acción o una omisión atribuible a dicho Estado, también cuando ese Estado apoye o tolere actos cometidos por sus nacionales u otras personas que tengan por objeto provocar la salida de extranjeros de su territorio en una forma no prevista por la ley"69. Por su parte, las expulsiones colectivas son el resultado del actuar de las autoridades estatales que, en ausencia de cualquier examen individualizado, sin haber recabado ninguna información respecto de las circunstancias personales y sin realizar ningún tipo de procedimiento de identificación de las personas migrantes, las obliga a abandonar el territorio, y en la mayoría de los casos las devuelven en frontera de manera inmediata ${ }^{70}$. Este tipo de expulsiones en específico serán abordadas en el segundo punto.

Las expulsiones encubiertas se prohíben porque implican una manera de vulneración, principalmente de los derechos procesales, que no debería ocurrir cuando el Estado decide llevar a cabo una decisión formal de expulsión, conforme a la ley y motivada, lo que tiene como consecuencia la apertura de un procedimiento administrativo regido por normas y derechos para las personas afectadas. En las expulsiones encubiertas, "el Estado expulsor, sin tomar una decisión formal de expulsión, adopta un comportamiento con el que pretende lograr, y de hecho logra, el mismo resultado, es decir, la salida forzosa del extranjero de su territorio"71.

Con relación a lo anterior, el Comité contra la Tortura (en adelante CAT, por sus siglas en inglés) ha establecido que "los Estados partes no deben adoptar medidas o políticas disuasorias como el internamiento en condiciones precarias durante períodos indefinidos, la negativa a tramitar solicitudes de asilo o la prolongación indebida de la tramitación, o la reducción de la asignación de fondos para programas de asistencia destinados a los solicitantes de asilo- que obligarían a personas que requieren protección a tenor de lo dispuesto en el artículo 3 de la Convención a

68 Ibídem, Artículo 5, Comentario 2), p. 29.

${ }^{69}$ Ibídem, Artículo 10, p. 15.

70 F. VACAS FERNÁNDEZ, El Derecho Migratorio, Internacional y Europeo, como Límite desde los Derechos Humanos a la Discrecionalidad de los Estados en Materia Migratoria, cit., p. 232.

71 Comisión de Derecho Internacional, Asamblea General de Naciones Unidas, Informe de la Comisión de Derecho Internacional $66^{\circ}$ período de sesiones, cit., Artículo 10, Comentario 3), p. 39. 
regresar a su país de origen pese al riesgo personal que correrían allí de ser sometidas a tortura u otros tratos o penas crueles, inhumanos o degradantes"72.

En sentido amplio, el dispositivo de control migratorio que deniega la entrada o la permanencia en un determinado Estado puede producirse en distintos momentos de la ruta migratoria $y$, también a partir de ello, puede contener diferentes denominaciones.

El proceso conocido como "retorno voluntario" es aquel que implica el retorno al Estado del que la persona migrante es nacional. En muchas ocasiones este proceso dista de ser voluntario, ya que las personas migrantes, principalmente en situación irregular, lo escogen bajo la amenaza de una expulsión forzosa. Es decir que "voluntariamente" deciden regresar a los países de los que emigraron, los cuales probablemente continúen en periodos de crisis $^{73}$.

El proceso por el cual un Estado, generalmente de tránsito, permite la admisión de personas no nacionales por parte de países de destino donde las personas se encuentran en situación migratoria irregular se conoce como "readmisión". Este proceso se materializa debido a unos acuerdos multilaterales 0 bilaterales sobre "readmisión"74. De acuerdo con Pérez Caramés, las readmisiones se llevan a cabo cuando las personas migrantes logran ingresar, de

72 Comité contra la Tortura de Naciones Unidas, Observación General No 4 (2017), relativa a la aplicación del artículo 3 de la Convención en el contexto del artículo 22, 4 de septiembre de 2018, CAT/C/GC/4, pár. 14, disponible en

https://undocs.org/es/CAT/C/GC/4 (última consulta: 30 de enero de 2020).

73 "En general, las condiciones en las que los migrantes solicitan el retorno voluntario asistido no permiten calificar el retorno de voluntario, ya que no reúnen los requisitos de una decisión plenamente informada, sin coacciones y respaldada por la disponibilidad de suficientes alternativas válidas, como los permisos temporales con fines de trabajo o estudio o de carácter humanitario o las oportunidades para la obtención de la residencia permanente o la nacionalidad. Algunos migrantes solicitan el retorno voluntario asistido porque se encuentran desesperados, a fin de evitar la expulsión o porque están detenidos, algunos de ellos indefinidamente, debido a la lentitud y complejidad de los procesos de reunificación familiar y de asilo, el riesgo de convertirse en indigentes, las malas condiciones de acogida o la retirada del apoyo social. El Relator Especial observa que los Estados y otros interesados que organizan retornos en el marco de un programa de retorno voluntario asistido a Estados que no son seguros y en los que los migrantes pueden ser objeto de violaciones de sus derechos humanos fundamentales pueden incurrir en una violación del principio de no devolución". Consejo de Derechos Humanos de la Asamblea General de Naciones Unidas, Informe del Relator Especial sobre los derechos humanos de los migrantes, cit., pár. 30. Vid. Consejo de Derechos Humanos de la Asamblea General de las Naciones Unidas, Visita al Níger Informe del Relator Especial sobre los derechos humanos de los migrantes, 16 de mayo de 2019, A/HRC/41/38/Add.1, pár. 46-54, disponible en https://undocs.org/es/A/HRC/41/38/Add.1 (última consulta: 30 de enero de 2020).

74 F. VACAS FERNÁNDEZ, El Derecho Migratorio, Internacional y Europeo, como Límite desde los Derechos Humanos a la Discrecionalidad de los Estados en Materia Migratoria, cit., p. 230. 
modo no autorizado, al territorio de un Estado y no han podido ser "devueltas" inmediatamente en frontera75.

Estos acuerdos multilaterales o bilaterales sobre gestión de flujos migratorios o de "readmisión" tienen como objetivo limitar la migración irregular en "países centrales" a través de la reconducción de personas migrantes en situación migratoria irregular a "terceros países" con los cuales han acordado -mejor dicho, intercambiado- la aceptación de personas migrantes por políticas de desarrollo o comerciales, así como permiso de estancia para sus nacionales ${ }^{76}$. Se observa con frecuencia que las prácticas que realizan, particularmente los Estados europeos de recepción de personas migrantes, están dirigidas a las devoluciones inmediatas de extranjeros a los países de tránsito, sin evaluar dos dimensiones de gran relevancia: 1) Si ese Estado que recibe a la persona expulsada lo reenviará a su país de origen; y 2) Si en ese Estado de tránsito al que la persona migrante fue devuelta podría sufrir tratos crueles, inhumanos 0 degradantes ${ }^{77}, y / 0$ podría ser sometida a una desaparición forzada78.

La puesta en marcha del mecanismo de control migratorio relacionado con las expulsiones o deportaciones no necesariamente está relacionada con la "repatriación" propiamente dicha -es decir, con la devolución de la persona a su país de origen o residencia-, sino que además están involucrados terceros países en la recepción de esas personas migrantes, como es el caso de las "readmisiones". Es así como se materializa, entre otras formas, la externalización de las fronteras, porque, como lo establecen De Genova y Peutz, se crean "zonas de amortiguación"79 en múltiples fronteras y múltiples

\footnotetext{
75 A. PÉREZ CARAMÉS, "La evolución reciente de las políticas de control migratorio en España", cit., p. 175.

76 C. WIHTOL DE WENDEN, El fenómeno migratorio en el siglo XXI. Migrantes, refugiados y relaciones internacionales, trad. de G. Vallejo Cervantes, $1^{\circ}$ edición en español, Fondo de Cultura Económica, México D.F., 2013, p. 184.

77 P. CERIANI CERNADAS, "Los derechos de los migrantes sin residencia legal en la Jurisprudencia del TEDH: Un balance complejo ante la realidad y retos de la inmigración en la región" en P. CERIANI CERNADAS y R. FAVA (eds.), Políticas migratorias y derechos humanos, Ediciones UNLa, 2009, pp. 173-243, pp. 198 y ss. 78 "Artículo 16.1: Ningún Estado Parte procederá a la expulsión, devolución, entrega o extradición de una persona a otro Estado cuando haya razones fundadas para creer que estaría en peligro de ser sometida a una desaparición forzada". Convención Internacional para la Protección de Todas las Personas contra las Desapariciones Forzadas, adoptada por la Asamblea General de Naciones Unidas en su resolución A/RES/61/177 del 20 de diciembre de 2006, disponible en https://undocs.org/es/A/RES/61/177 (última consulta: 30 de enero de 2020).

79 En el original, "buffer zone". N. DE GENOVA y N. PEUTZ, "Introduction" en N. DE GENOVA y N. PEUTZ (eds.), The Deportation Regime. Sovereignty, Space, and the Freedom of Movement, Duke University Press, Estados Unidos, 2010, pp. 1-29, p. 5. (La traducción me pertenece).
} 
Estados, en los que "desechar"80 a las personas migrantes, e incluso recluirlas en centros de detención ${ }^{81}$.

La "devolución" o "rechazo en frontera" es también un procedimiento administrativo reglado que se lleva a cabo cuando se deniega la entrada a una persona al territorio al que quiere ingresar. Todo aquel acto que no se realice de acuerdo a los procedimientos establecidos y de conformidad con los derechos de las personas migrantes supone una expulsión de hecho que contraviene normativa internacional.

Particularmente en España, se ha popularizado la expresión "devoluciones o expulsiones en caliente"82 y refiere a la práctica

${ }^{80}$ Vid. Z. BAUMAN, Archipiélagos de excepciones, cit.

81 Un claro ejemplo de ello es el acuerdo firmado por Australia con Papúa Nueva Guinea y con Nauru conocido como "La solución del Pacífico" y que tiene por objetivo evitar que las personas migrantes y solicitantes de asilo lleguen a Australia. Por lo tanto, este último se compromete al pago de una gran suma de dinero para que las Islas de Papúa Nueva Guinea y Nauru acepten en sus territorios -y priven de su libertad en centros de detención- a las personas migrantes y solicitantes de asilo interceptadas en alta mar. De acuerdo con White, en lugar de ser acuerdos de cooperación, son acuerdos de evasión de responsabilidades y obligaciones jurídicas internacionalmente reconocidas por parte de países centrales aprovechando las necesidades económicas de países periféricos. C. C. WHITE, "Australia's Boatpeople Policy: Regional Cooperation or Passing the Buck?", Cultural Encounters, Conflicts, and Resolutions, vol. 1, Iss. 1, artículo 8, 2014, pp. 1-21, disponible en

https://engagedscholarship.csuohio.edu/cgi/viewcontent.cgi?article $=1006 \&$ context =cecr (última consulta: 30 de enero de 2020). (La traducción me pertenece). Vid. Parliament of Australia, Department of Parliamentary Services, The "Pacific Solution" revisited: a statistical guide to the asylum seeker caseloads on Nauru and Manus Island, 4 de septiembre de 2012, disponible en

https://parlinfo.aph.gov.au/parlInfo/download/library/prspub/1893669/upload_bina ry/1893669.pdf; fileType=application/pdf (última consulta: 30 de enero de 2020); Vid. "Australia firma acuerdo con Nauru para recluir en la isla micronesia a demandantes de asilo", 6 de agosto de 2013, disponible en

https://islasdelpacifico.wordpress.com/2013/08/06/australia-firma-acuerdo-con-

nauru-para-recluir-en-la-isla-micronesia-a-demandantes-de-asilo/ (última consulta: 30 de enero de 2020); Vid. "«Pacific solution», deportando a los solicitantes de asilo en Australia a remotas islas del Pacífico", 30 de abril de 2013, disponible en https://islasdelpacifico.wordpress.com/2013/04/30/19177/ (última consulta: 30 de enero de 2020); Vid. N. GALARRAGA GORTÁZAR, "Misión: disuadir a los refugiados", El País, 28 de octubre de 2017, disponible en

https://elpais.com/internacional/2017/10/27/actualidad/1509094341_467132.html (última consulta: 30 de enero de 2020); Vid. "Australia reabrirá el centro de retención de migrantes de isla de Navidad", El País, 13 de febrero de 2019, disponible en

https://elpais.com/internacional/2019/02/13/actualidad/1550056305_443124.html (última consulta: 30 de enero de 2020).

82 Sin embargo, el origen de la frase, aunque con otro significado, no es peculiar de España. Se trata de una práctica de cooperación policial derivada del Espacio Schengen, Ilamada "persecución en caliente", que permite perseguir a personas que han cometido un delito, sorprendidos in fraganti, más allá de las fronteras del Estado donde se inició la persecución, pero que debe cumplir con obligaciones muy precisas. "Artículo 41. 1. Los agentes de una de las Partes contratantes que, en su país, están siguiendo a una persona hallada en flagrante delito de comisión de una 
llevada a cabo por las Fuerzas y Cuerpos de Seguridad del Estado, en los enclaves territoriales de Ceuta y Melilla y desde los islotes sujetos a soberanía española, por la cual, por vía de hecho, se "devuelve" a las autoridades marroquís a las personas migrantes interceptadas en la frontera o zonas de soberanía del Estado español, sin cumplir con ninguno de los requerimientos legalmente establecidos del procedimiento ni respetar las garantías y derechos internacionalmente reconocidos ${ }^{83}$. Las devoluciones en caliente, de acuerdo con la definición de expulsiones colectivas, formaría parte de las mismas ${ }^{84}$. Por esta práctica, el gobierno español ha sido condenado por el TEDH en la sentencia N. D. y N. T. contra España de 201785, aunque el Estado español ha recurrido la sentencia del TEDH a la Gran Sala, y a la fecha de hoy no se ha decidido sobre el tema ${ }^{86}$. Incluso, si bien las devoluciones en caliente son una práctica

de las infracciones mencionadas en el apartado 4 o de la participación en una de dichas infracciones estarán autorizados a proseguir la persecución sin autorización previa en el territorio de otra Parte contratante cuando las autoridades competentes de la otra Parte contratante, debido a la especial urgencia, no hayan podido ser advertidas previamente de la entrada en el territorio por uno de los medios de comunicación mencionados en el artículo 44, o cuando dichas autoridades no hayan podido personarse en el lugar con tiempo suficiente para reanudar la persecución (...)". Convenio de aplicación del Acuerdo de Schengen de 14 de junio de 1985, cit. No obstante, en el caso concreto de las devoluciones en caliente no aplica este artículo ya que la migración irregular no es un delito.

83 M. MARTÍNEZ ESCAMILLA, "Devoluciones en caliente. Un análisis jurídico" en J. L. VILLENA HIGUERAS (coord.), Derechos humanos y justicia universal en la frontera sur, Universidad de Granada, Granada, 2016, pp. 77-96, pp. 78 y 79.

84 Á. SOLANES CORELLA, "Contra la normalización de la ilegalidad: la protección judicial de los extranjeros frente a las expulsiones colectivas y las devoluciones «en caliente»", Cuadernos Electrónicos de Filosofía del Derecho (CEFD), núm. 36, 2017, pp. 195-225, p. 206.

85 TEDH, N. D. y N. T. contra España, de 3 de octubre de 2017, en las demandas no $8675 / 15$ y $8697 / 15$, expulsión colectiva, disponible en

https://www.refworld.org.es/docid/5a04a4da4.htmlm (última consulta: 30 de enero de 2020). Aunque la sentencia hace alusión a la frontera terrestre en España y Marruecos, y precisamente a las vallas fronterizas en Melilla, las expulsiones o devoluciones en caliente son llevadas a cabo, también, cuando las personas migrantes intentan ingresar a territorio español por mar, ya sea porque han "alcanzado alguna de las islas de soberanía española situadas frente a las costas de Marruecos o han entrado a nado o en embarcaciones en aguas de soberanía español". M. MARTÍNEZ ESCAMILLA, "Devoluciones en caliente. Un análisis jurídico", cit., p. 79.

86 Si bien a la fecha de escritura de esta ponencia la Gran Sala del TEDH no había decidido sobre el tema, es necesario destacar que hubo resolución con fecha 13 de febrero de 2020. En este sentido, la Gran Sala revocó la sentencia de la tercera sección de la Sala del TEDH y sostuvo que España no violó el Convenio Europeo de Derechos Humanos. Por lo tanto, consideró que no se cometieron expulsiones colectivas ni se vulneró el derecho a un recurso efectivo. El estudio de la sentencia de la Gran Sala requiere de un análisis exhaustivo (y crítico), debido al retroceso en la protección de los derechos de las personas en contextos de movilidad humana y a la contradicción con la propia jurisprudencia del TEDH, que excede el objeto de esta ponencia. La sentencia de la Gran Sala se encuentra disponible en http://hudoc.echr.coe.int/eng?i=001-201353 
prohibida en múltiples instrumentos de reconocimiento y protección de derechos, han sido "legalizadas" a partir de la sanción de la "Ley Mordaza" en España en 201587.

Aunque desde los sistemas de protección internacional de los derechos humanos se han regulado los mecanismos de expulsión y de garantía de derechos de las personas contra quienes se aplicarán tales medidas, algunas de las disposiciones contenidas en dichos articulados solo se refieren a las personas migrantes en situación migratoria regular. Por ejemplo, en el sistema universal de protección de derechos humanos el artículo 13 del PIDCP88, y en los sistemas regionales de protección de derechos humanos, el artículo $1^{\circ}$ del Protocolo no 7 al $\mathrm{CEDH}^{89}$, el artículo 22.6 de la Convención Americana sobre Derechos Humanos (en adelante $\mathrm{CADH}$ ) ${ }^{90}$ y el artículo 12.4 de la Carta Africana sobre Derechos Humanos y de los pueblos ${ }^{91}$, hacen expresa mención a la "legalidad" de la estancia de la persona a la que se le apliquen las garantías de protección de sus derechos al momento de ejecutarse una expulsión. Sin embargo, de acuerdo a los

87 Ley Orgánica 4/2015, del 30 de marzo, de protección de la seguridad ciudadana (BOE núm. 77, del 31 marzo de 2015), disponible en https://boe.es/buscar/doc.php?id=BOE-A-2015-3442 (última consulta: 30 de enero de 2020).

88 "Artículo 13: El extranjero que se halle legalmente en el territorio de un Estado Parte en el presente Pacto sólo podrá ser expulsado de él en cumplimiento de una decisión adoptada conforme a la ley; y, a menos que razones imperiosas de seguridad nacional se opongan a ello, se permitirá a tal extranjero exponer las razones que lo asistan en contra de su expulsión, así como someter su caso a revisión ante la autoridad competente o bien ante la persona o personas designadas especialmente por dicha autoridad competente, y hacerse representar con tal fin ante ellas". (El destacado me pertenece). Pacto Internacional de Derechos Civiles y Políticos, adoptado por la Asamblea General de Naciones Unidas en su resolución 2200 A (XXI) de 16 de diciembre de 1966, disponible en https://www.ohchr.org/sp/professionalinterest/pages/ccpr.aspx (última consulta: 30 de enero de 2020).

89 "Artículo 1: El extranjero que resida legalmente en el territorio de un Estado solamente podrá ser expulsado en ejecución de una resolución adoptada conforme a la ley (...)". (El destacado me pertenece). Protocolo $n^{\circ} 7$ al Convenio para la Protección de los Derechos Humanos y de las Libertades Fundamentales, adoptado por el Consejo de Europa el 22 de noviembre de 1984, disponible en https://www.echr.coe.int/Documents/Convention_SPA.pdf (última consulta: 30 de enero de 2020).

90 "Artículo 22.6: El extranjero que se halle legalmente en el territorio de un Estado parte en la presente Convención, sólo podrá ser expulsado de él en cumplimiento de una decisión adoptada conforme a la ley". (El destacado me pertenece). Convención Americana sobre Derechos Humanos (Pacto de San José), 22 de noviembre de 1969, disponible en https://www.oas.org/dil/esp/tratados_b32_convencion_americana_sobre_derechos_humanos.htm (última consulta: 30 de enero de 2020).

91 "Artículo 12. 4. Un extranjero legalmente admitido en un territorio de un Estado firmante de la presente Carta, sólo puede ser expulsado de él en virtud de una decisión tomada de conformidad con la ley". (El destacado me pertenece). Carta Africana sobre Derechos Humanos y de los Pueblos, 27 de julio de 1981, disponible en http://www.derechoshumanos.net/normativa/normas/africa/CAFDH/1981CAFDH.htm (última consulta: 30 de enero de 2020). 
principios del Derecho internacional de los derechos humanos, como son el principio de no devolución ${ }^{92}$; de universalidad, de igualdad y no discriminación 93 ; pro homine, de dinamismo y carácter evolutivo ${ }^{94}$; con los análisis específicos realizados por comités y organismos especiales sobre el articulado de las convenciones; y con la jurisprudencia internacional, la exigencia de la regularidad en la estancia para que se apliquen las garantías de derechos en los mecanismos de expulsión es cuestionable ${ }^{95}$.

92 El principio de no devolución comprende la aplicación de garantías, principalmente relacionada con la tutela judicial efectiva, por las cuales para que se lleve a cabo la expulsión o "devolución" de una persona migrante debe realizarse de manera previa un análisis personalizado de su caso, por lo cual la decisión de expulsión o "devolución" debe ser motivada y recurrible, y no debe implicar un peligro para la vida o integridad de la persona "devuelta".

$93 \mathrm{El}$ artículo $1^{\circ}$ de la DUDH afirma que "todos los seres humanos nacen libres e iguales en dignidad y derechos"; por lo tanto, cualquier limitación a dichos principios de ser absolutamente excepcional. Por su parte, el PIDCP establece, por un lado en el artículo 2, primer párrafo, que "cada uno de los Estados Partes en el presente Pacto se compromete a respetar y a garantizar a todos los individuos que se encuentren en su territorio y estén sujetos a su jurisdicción los derechos reconocidos en el presente Pacto, sin distinción alguna de raza, color, sexo, idioma, religión, opinión política o de otra índole, origen nacional o social, posición económica, nacimiento o cualquier otra condición social", y también hace referencia al principio de igualdad y no discriminación en el artículo 26, que ya ha sido referenciado. El Pacto de Derechos Económicos, Sociales y Culturales, en al artículo 2, párrafo 2 establece que "los Estados Partes en el presente Pacto se comprometen a garantizar el ejercicio de los derechos que en él se enuncian, sin discriminación alguna por motivos de raza, color, sexo, idioma, religión, opinión política o de otra índole, origen nacional o social, posición económica, nacimiento o cualquier otra condición social". Pacto Internacional de Derechos Económicos, Sociales y Culturales, adoptado por la Asamblea General de Naciones Unidas en su resolución 2200 A (XXI), del 16 de diciembre de 1966, disponible en https://www.ohchr.org/sp/professionalinterest/pages/cescr.aspx (última consulta: 30 de enero de 2020).

94 El principio de dinamismo refiere a la necesidad de interpretar la normativa a la luz de las circunstancias actuales, es decir, como "instrumentos vivos". El carácter evolutivo o principio de progresividad implica la adopción de medidas y/o la interpretación de las normas que impliquen la ampliación en la garantía de los derechos humanos. Por su parte, el principio pro homine obliga a la aplicación y/o interpretación de la norma que más favorezca la protección de los derechos de la persona. P. CERIANI CERNADAS, "Los derechos políticos de extranjeros en España desde un enfoque de derechos humanos: la ilegitimidad del principio de reciprocidad", en J. DE LUCAS y Á. SOLANES CORELLA (eds.), La igualdad en los derechos: claves de la integración, Dykinson, Madrid, 2009, pp. 481-519, p. 511. El TEDH, en el caso Rantsev contra Chipre y Rusia, en el párrafo 277 hace referencia a que el CEDH es un instrumento vivo que debe ser interpretado a la luz de las condiciones actuales. TEDH, Rantsev contra Chipre y Rusia, del 7 de enero de 2010, en la demanda $n^{\circ}$ 25965/04, disponible en http://hudoc.echr.coe.int/eng?i=001139059 (última consulta: 30 de enero de 2020).

95 La Corte Interamericana de Derechos Humanos "considera que el derecho al debido proceso legal debe ser reconocido en el marco de las garantías mínimas que se deben brindar a todo migrante, independientemente de su estatus migratorio. El amplio alcance de la intangibilidad del debido proceso se aplica no solo ratione materiae sino también ratione personae sin discriminación alguna". Corte 
Por su parte, la Convención Internacional sobre la Protección de los Derechos de Todos los Trabajadores Migratorios y de sus Familiares, al regular las garantías aplicables a los procesos de expulsión no realiza ninguna especificación respecto a la regularidad o irregularidad de la estancia de las personas migrantes ${ }^{96}$. Sin embargo, es importante destacar que esta Convención no ha sido ratificada por la mayoría de Estados receptores de migrantes ${ }^{97}$.

Cuando un Estado toma la decisión de expulsar a una persona de su territorio y/o jurisdicción, esta debe cumplir las siguientes garantías procesales: a) las expulsiones deben ser decisiones adoptadas conforme a la ley, para impedir, de esta manera, las expulsiones arbitrarias; b) las decisiones deberán responder a cada caso particular, en oposición a las expulsiones colectivas; c) las personas migrantes a quienes se les aplica tal medida tienen derecho a argumentar contra la decisión y a solicitar la revisión ante autoridad competente; por último, d) las personas tienen derecho a una representación legal98. Por lo tanto, es preciso subrayar que los procedimientos de expulsión deben estar regidos conforme a normas y garantías que respeten los derechos humanos.

Además, en cualquier supuesto de expulsión, los Estados tienen la obligación de respetar el principio de no devolución -non refoulement-, es decir, el Estado debe realizar un análisis personalizado y motivado para garantizar que la expulsión o devolución, al país de origen o a un tercer país, no implicará un

Interamericana de Derechos Humanos, Opinión Consultiva OC-18/03 "Condición Jurídica y Derechos de los Migrantes Indocumentados", 17 de septiembre de 2003, pár. 122, disponible en

http://www.corteidh.or.cr/docs/opiniones/seriea_18_esp.pdf (última consulta: 30 de enero de 2020). Vid. Asamblea General de Naciones Unidas, Proyecto de documento final de la Conferencia Intergubernamental encargada de Aprobar el Pacto Mundial para la Migración Segura, Ordenada y Regular, cit. Vid. Comité de Derechos Humanos de Naciones Unidas, Observación General No 31 [80]: Naturaleza de la obligación jurídica general impuesta a los Estados Partes en el Pacto, 26 de mayo de 2004, CCPR/C/21/Rev.1/Add.13, pár. 10, disponible en https://www.refworld.org.es/docid/478b26ea2.html (última consulta: 30 de enero de 2020). Vid. Comité de Derechos Humanos de Naciones Unidas, Observación General $N^{\circ}$ 15: La situación de los extranjeros con arreglo al Pacto, 11 de abril de 1986, $27^{\circ}$ período de sesiones, disponible en

https://www.acnur.org/fileadmin/Documentos/BDL/2001/1403.pdf

(última consulta: 30 de enero de 2020).

96 Artículo 22. Convención Internacional sobre la Protección de los Derechos de Todos los Trabajadores Migratorios y de sus Familiares, adoptada por la Asamblea General en su resolución 45/158, del 18 de diciembre de 1990, disponible en https://www.ohchr.org/sp/professionalinterest/pages/cmw.aspx (última consulta: 30 de enero de 2020).

97 Solo 55 Estados han ratificado esta Convención, y ningún país de la Unión Europea lo ha hecho.

98 Comité de Derechos Humanos de Naciones Unidas, Observación General $N^{\circ} 15$ : La situación de los extranjeros con arreglo al Pacto, cit., pár. 10 y Artículo 22. Convención Internacional sobre la Protección de los Derechos de Todos los Trabajadores Migratorios y de sus Familiares, cit. 
peligro para la vida o la libertad de la persona. ${ }^{99}$. Este principio, que ha estado asociado tradicionalmente a las personas solicitantes de asilo y su articulado en la Convención de 1951 sobre refugiados ${ }^{100}$, ha trascendido esta única esfera de protección y es un principio considerado por el Derecho internacional como norma imperativa: ius cogens. Es decir que es obligatorio para todos los Estados ${ }^{101}$.

En ese sentido, el CAT, en la Observación General No 4, consideró que "todos los Estados partes deben aplicar el principio de no devolución en todo territorio que esté bajo su jurisdicción o en toda zona sujeta a su control o autoridad (...) a todas las personas, incluidas las que soliciten o necesiten protección internacional, sin ningún tipo de discriminación e independientemente de la nacionalidad de la persona o de su condición de apatridia, si es el caso, y de su situación jurídica, administrativa o judicial, en circunstancias normales o en estado de emergencia"102. En línea con los argumentos, el mismo CAT, unos años antes, en la Observación General No 2, sostuvo que "el concepto de «todo territorio que esté bajo su jurisdicción» (...) incluye cualquier territorio o instalación y es aplicable para proteger a toda persona, sea o no nacional y sin discriminación, que esté sujeta al control de jure o de facto de un Estado Parte"103.

99 Vid. Comité contra la Tortura de Naciones Unidas, Observación General $N^{\circ} 4$ (2017), relativa a la aplicación del artículo 3 de la Convención en el contexto del artículo 22, cit., pár. 18, III. Medidas preventivas para garantizar el principio de no devolución.

100 "Artículo 33. Prohibición de expulsión y de devolución («refoulement») 1. Ningún Estado Contratante podrá, por expulsión o devolución, poner en modo alguno a un refugiado en las fronteras de los territorios donde su vida o su libertad peligre por causa de su raza, religión, nacionalidad, pertenencia a determinado grupo social, o de sus opiniones políticas. 2. Sin embargo, no podrá invocar los beneficios de la presente disposición el refugiado que sea considerado, por razones fundadas, como un peligro para la seguridad del país donde se encuentra, o que, habiendo sido objeto de una condena definitiva por un delito particularmente grave, constituya una amenaza para la comunidad de tal país". Convención sobre el Estatuto de los Refugiados, adoptada por la Conferencia de Plenipotenciarios sobre el Estatuto de los Refugiados y de los Apátridas (Naciones Unidas), convocada por la Asamblea General en su resolución 429 (V), el 28 de julio de 1951 en Ginebra, Suiza, disponible en https://www.acnur.org/5b0766944.pdf (última consulta: 30 de enero de 2020).

101 C. PÉREZ GONZÁLEZ, "Límites a la lucha contra la inmigración irregular por vía marítima impuestos por el derecho internacional de los derechos humanos" en L. L. HIERRO (coord.), Autonomía individual frente a autonomía colectiva. Derechos en conflicto, Marcial Pons, Madrid, 2014, pp. 193-218, p. 205.

102 Comité contra la Tortura de Naciones Unidas, Observación General No 4 (2017), relativa a la aplicación del artículo 3 de la Convención en el contexto del artículo 22, cit., pár. 10.

103 Comité contra la Tortura de Naciones Unidas, Observación General No 2, aplicación del artículo 2 por los Estados Partes, 24 de enero de 2008, CAT/C/GC/2, pár. 7, disponible en https://www.refworld.org.es/docid/5d7fcb5ea.html (última consulta: 30 de enero de 2020). 
La protección del principio de no devolución puede ser violado, también, de manera indirecta, es decir que el Estado que lleva a cabo la devolución o expulsión de una persona no solo debe cerciorarse que el Estado al cual envía a esa persona (que puede ser el de origen, el de residencia e incluso un tercer país) no ponga en riesgo su vida e integridad física, sino que ese Estado no enviará a la persona a otro país en que dichos derechos puedan estar en peligro ${ }^{104}$.

La garantía del principio de no devolución a toda persona puede ser interpretado de lo que dispone el artículo 22.8 de la $\mathrm{CADH}^{105}$, el artículo 3 del $\mathrm{CEDH}^{106}$, el artículo 5 de la Carta Africana de Derechos Humanos y de los Pueblos ${ }^{107}$, el artículo 3 de la Convención contra la Tortura y Otros Tratos o Penas Crueles, Inhumanos o Degradantes ${ }^{108}$, y el artículo 16.1 de la Convención Internacional para la Protección de Todas las Personas contra las Desapariciones Forzadas ${ }^{109}$. En cuanto al ámbito de la UE, es el artículo 19.2 de la Carta de Derechos Fundamentales ${ }^{110}$ el que garantiza el principio de no devolución.

104 Vid. TEDH, T. I. contra Reino Unido, del 7 de marzo de 2000, en la decisión de admisibilidad demanda $n^{\circ} 43844 / 98$, disponible en

http://hudoc.echr.coe.int/eng?i=001-5105 (última consulta: 30 de enero de 2020). 105 "Artículo 22.8: En ningún caso el extranjero puede ser expulsado o devuelto a otro país, sea o no de origen, donde su derecho a la vida o a la libertad personal está en riesgo de violación a causa de raza, nacionalidad, religión, condición social o de sus opiniones políticas", Convención Americana sobre Derechos Humanos (Pacto de San José), cit.

106 "Artículo 3. Prohibición de la tortura. Nadie podrá ser sometido a tortura ni a penas o tratos inhumanos o degradantes". Convenio Europeo para la Protección de los Derechos Humanos y de las Libertades Fundamentales, adoptado por el Consejo de Europa el 4 de noviembre de 1950, entrada en vigor: 1953, disponible en https://www.echr.coe.int/Documents/Convention_SPA.pdf (última consulta: 30 de enero de 2020).

107 "Artículo 5. Todo individuo tendrá derecho al respeto de la dignidad inherente al ser humano y al reconocimiento de su status legal. Todas las formas de explotación y degradación del hombre, especialmente la esclavitud, el comercio de esclavos, la tortura, el castigo y el trato cruel, inhumano o degradante, serán prohibidos". Carta Africana sobre Derechos Humanos y de los Pueblos, cit.

108 "Artículo 3. 1. Ningún Estado Parte procederá a la expulsión, devolución o extradición de una persona a otro Estado cuando haya razones fundadas para creer que estaría en peligro de ser sometida a tortura. 2. A los efectos de determinar si existen esas razones, las autoridades competentes tendrán en cuenta todas las consideraciones pertinentes, inclusive, cuando proceda, la existencia en el Estado de que se trate de un cuadro persistente de violaciones manifiestas, patentes 0 masivas de los derechos humanos". Convención contra la Tortura y Otros Tratos o Penas Crueles, Inhumanos o Degradantes, adoptada y abierta a la firma, ratificación y adhesión por la Asamblea General en su resolución 39/46, del 10 de diciembre de 1984, entrada en vigor: 26 de junio de 1987, disponible en https://www.ohchr.org/sp/professionalinterest/pages/cat.aspx (última consulta: 30 de enero de 2020).

109 Ut Supra nota 78.

110 "Artículo 19. Protección en caso de devolución, expulsión y extradición. 2. Nadie podrá ser devuelto, expulsado o extraditado a un Estado en el que corra un grave riesgo de ser sometido a la pena de muerte, a tortura o a otras penas o tratos 
En efecto, aunque el CEDH no contiene una alusión explícita a la protección de dicho principio, la interpretación que ha realizado el TEDH sobre el artículo 3 ampara el principio de no devolución, y de esta manera se prohíbe a los Estados a expulsar a las personas migrantes a un país del que existan motivos suficientes para considerar que la persona puede ser sometida a tortura, penas, tratos inhumanos o degradantes. Por lo tanto, los Estados tienen la obligación de asegurarse sobre el trato que recibirán las personas migrantes que intentan expulsar, ya sea a sus países de origen, de residencia o terceros países ${ }^{111}$.

Por lo cual, del principio de no devolución se deduce uno de los límites a la soberanía del Estado de establecer las condiciones de admisión y permanencia de personas migrantes en su territorio. La persona migrante tendrá derecho a permanecer en un Estado del que no es nacional, incluso si estuviera en situación administrativa irregular, cuando el Derecho internacional de los derechos humanos establezca que dicho Estado tiene la obligación de no expulsarlo ${ }^{112}$.

Estos mecanismos de control migratorio -expulsiones 0 devoluciones- ponen en juego derechos fundamentales ${ }^{113}$ de las personas migrantes. Por ello, por un lado, es necesario que esos derechos sean garantizados y protegidos, y por el otro, que estos mecanismos de control migratorio sean procedimientos regulados con garantías procesales, para que las personas migrantes puedan defenderse ante situaciones de vulneración.

Con relación a lo que a los fines de la protección de los derechos humanos atañe, es necesario observar, más allá de la denominación y el momento en que se realiza, cuál es la legalidad de la política o práctica pública o de la decisión particular que se adopta, y en su caso si la persona afectada ha podido defenderse y cuáles son los efectos en sus derechos que tal medida implica. Además, es preciso analizar la proporcionalidad entre los derechos vulnerados al consumarse una expulsión o devolución y el bien jurídico protegido por los Estados, que por lo general están relacionados con la seguridad, el orden público, la cohesión social, entre otros, versus el derecho a la vida, el derecho a no ser sometido a tortura, tratos o

inhumanos o degradantes". Carta de los Derechos Fundamentales de la Unión Europea, 30 marzo de 2010, (2010/C 83/02), disponible en

https://www.boe.es/doue/2010/083/Z00389-00403.pdf (última consulta: 30 de enero de 2020).

111 M. MARTÍNEZ ESCAMILLA, "Devoluciones en caliente. Un análisis jurídico", cit., p. 92.

112 C. PÉREZ GONZÁLEZ, "Límites a la lucha contra la inmigración irregular por vía marítima impuestos por el derecho internacional de los derechos humanos", cit., p. 200.

113 Entre ellos, el derecho a la vida, el derecho a no ser sometido a tortura, tratos o penas crueles, inhumanos o degradantes, el derecho a la vida privada y familiar, el derecho a un proceso equitativo. Vid. M. D. BOLLO AROCENA, Expulsión de extranjeros, derecho internacional y derecho europeo, Thomson Reuters Aranzadi, Pamplona, 2016. 
penas crueles, inhumanos o degradantes, el derecho a la vida privada y familiar.

\section{2.- Expulsiones colectivas en Europa}

La CDI, en el proyecto de artículos sobre la expulsión de extranjeros, define, en el artículo 9.1, a las expulsiones colectivas como aquellas expulsiones de extranjeros como grupo, y en el artículo 9.2 establece su prohibición. Asimismo, en el artículo 9.3 establece que "un Estado podrá expulsar conjuntamente a los miembros de un grupo de extranjeros siempre que la medida de expulsión se adopte al término y sobre la base de una evaluación de la situación particular de cada uno de los miembros que integran el grupo"114. Es decir que lo determinante en las expulsiones colectivas no recae, principalmente, en el número que compone el grupo de personas extranjeros a expulsar - lo que equivaldría a un criterio meramente cuantitativo-, sino que en la ejecución de esta clase de expulsiones no se garantiza la posibilidad de realizar alegaciones personales, ni existe la constancia de quién es la persona sujeta de expulsión, incluso si esa persona está necesitada de una especial protección -lo que representaría un criterio cualitativo-115.

Dicho de otra manera, lo "colectivo" no está determinado únicamente por el número de personas que han sido expulsadas en el mismo momento, ni por el hecho de que las personas sean todas de la misma nacionalidad, sino por la ausencia de un análisis individualizado de cada caso particular. Debido a la afectación de derechos que implica la expulsión de una persona de un Estado, ese análisis debe ser razonable, adecuado, justo y respetuoso de las garantías legales ${ }^{116}$.

No obstante, no se considerarán expulsiones colectivas aquellas en las que varias personas extranjeras hayan sido objeto de decisiones similares, incluso redacciones estandarizadas, si la situación de cada una de esas personas ha sido analizada individualmente $\mathrm{y}$ ha tenido el derecho de impugnar ante las autoridades competentes la medida de expulsión ${ }^{117}$.

En resumen, las expulsiones colectivas son el resultado del actuar de las autoridades estatales que, en ausencia de cualquier

114 En ausencia de otra definición de expulsiones colectivas en instrumentos internacionales, es menester recurrir a la dada por la Comisión de Derecho Internacional, Asamblea General de Naciones Unidas, Informe de la Comisión de Derecho Internacional $66^{\circ}$ período de sesiones, cit. Tampoco en el marco de Europa, ni el CEDH ni el Protocolo $n^{\circ} 4$ al CEDH, brindan una definición sobre las expulsiones colectivas.

115 M. MARTÍNEZ ESCAMILLA, "Devoluciones en caliente. Un análisis jurídico", cit., p. 91.

116 Á. SOLANES CORELLA, "Contra la normalización de la ilegalidad: la protección judicial de los extranjeros frente a las expulsiones colectivas y las devoluciones «en caliente»", cit., p. 206.

117 TEDH, Hirsi Jamaa y otros contra Italia, cit., pár. 184. 
examen individualizado, sin haber recabado ninguna información respecto de las circunstancias personales y sin realizar ningún tipo de procedimiento de identificación de las personas migrantes, las expulsan o devuelven; y este accionar sucede, principalmente, de manera inmediata y en las fronteras.

A pesar de que las expulsiones colectivas de personas migrantes están prohibidas en diversos instrumentos de Derecho internacional de los derechos humanos, son una práctica común en el control de los flujos migratorios. Y, más aún, en el ámbito de las fronteras, justificadas en el argumento de la soberanía del Estado, la seguridad y el orden público. Conforme con Solanes Corella, estas prácticas reproducidas sistemáticamente cristalizan la "normalización de la ilegalidad"118.

En lo que se refiere a Europa, tanto el Derecho de la Unión Europea como el CEDH prohíben las expulsiones colectivas. El Derecho de la UE lo establece en el artículo 19.1 de la Carta de Derechos Fundamentales de la UE ${ }^{119}$, en el artículo 78 del Tratado de Funcionamiento de la $U^{120}$ y en el artículo 19.8 de la Carta Social Europea $^{121}$, que exige que el acervo comunitario en materia de asilo sea conforme a los demás tratados pertinentes.

En el ámbito del Consejo de Europa, las expulsiones colectivas están prohibidas en el artículo 4 del Protocolo $n^{\circ} 4$ al $\mathrm{CEDH}^{122}$. El

118 Á. SOLANES CORELLA, "Contra la normalización de la ilegalidad: la protección judicial de los extranjeros frente a las expulsiones colectivas y las devoluciones «en caliente»", cit., pp. 195-196.

119 "Artículo 19.1. Se prohíben las expulsiones colectivas". Carta de los Derechos Fundamentales de la Unión Europea, cit.

120 "Artículo 78. (antiguos artículos 63, puntos 1 y 2, y 64, apartado 2, TCE). 1. La Unión desarrollará una política común en materia de asilo, protección subsidiaria y protección temporal destinada a ofrecer un estatuto apropiado a todo nacional de un tercer país que necesite protección internacional y a garantizar el respeto del principio de no devolución. Esta política deberá ajustarse a la Convención de Ginebra de 28 de julio de 1951 y al Protocolo de 31 de enero de 1967 sobre el Estatuto de los Refugiados, así como a los demás tratados pertinentes". Versión consolidada del Tratado de Funcionamiento de la Unión Europea, 26 de octubre de 2012, (2012/C 326/01), disponible en https://eur-lex.europa.eu/legalcontent/es/ALL/?uri=CELEX\%3A12012E\%2FTXT (última consulta: 30 de enero de 2020).

121 "Artículo 19. Derecho de los trabajadores migrantes y sus familias a protección y a asistencia. Para garantizar el ejercicio efectivo del derecho de los trabajadores migrantes y sus familias a protección y asistencia en el territorio de cualquier otra Parte Contratante, las Partes Contratantes se comprometen: 8. A garantizar a dichos trabajadores, cuando residan legalmente dentro de su territorio, que no podrán ser expulsados, excepto si amenazaren la seguridad del Estado o atentaren contra el orden público o las buenas costumbres". Carta Social Europea, adoptada por el Consejo de Europa el 18 de octubre de 1961, Turín, disponible en https://www.boe.es/buscar/act.php?id=BOE-A-1980-13567 (última consulta: 30 de enero de 2020).

122 "Artículo 4. Prohibición de las expulsiones colectivas de extranjeros. Quedan prohibidas las expulsiones colectivas de extranjeros". Protocolo $n^{\circ} 4$ al Convenio para la Protección de los Derechos Humanos y de las Libertades Fundamentales que reconoce ciertos derechos y libertades además de los que ya figuran en el Convenio 
Protocolo se redactó en 1963 y constituyó el primer instrumento internacional que plasmó la prohibición de las expulsiones colectivas, que no había sido incluida explícitamente en los artículos del CEDH redactada en $1950^{123}$. La inclusión de este artículo en el Protocolo no 4 radicaba en la necesidad de evitar, y prohibir formalmente, expulsiones colectivas como las que habían sucedido en el pasado ${ }^{124}$.

En efecto, la prohibición de las expulsiones colectivas se enmarca en la protección de la persona migrante ante la acción del Estado que lo obliga a abandonar su territorio. De este modo, es preciso garantizar, previamente, el examen individual de las circunstancias personales, y de adoptarse una medida de expulsión o devolución, la persona migrante tendrá el derecho de argumentar contra la medida dictada por la autoridad ${ }^{125}$. Es una obligación para el Estado que esa medida sea dictada por autoridad competente, motivada, proporcional y conforme a la ley. Se entiende por autoridad competente aquella "con capacidad de valorar en su totalidad la argumentación ofrecida contra la expulsión, entrenado adecuadamente en los estándares de derecho nacional e internacional, y estando en condiciones de corroborar los elementos relevantes en caso necesario"126.

También es relevante remarcar que la persona migrante no solo tiene derecho a que la expulsión sea realizada como consecuencia de un examen individual, conforme a la ley, motivada y adoptada por autoridad competente, sino que también la persona tiene derecho a recurrir, de manera efectiva, la decisión. Es decir que para garantizar ese derecho se debe respetar y promover el derecho a ser oído, el efecto suspensivo del recurso, el acceso a una representación y asistencia legal, y el acceso a intérprete ${ }^{127}$.

$y$ en el primer Protocolo adicional al Convenio, modificado por el Protocolo $n^{\circ} 11$, adoptado por el Consejo de Europa el 16 de septiembre de 1963, entrada en vigor: 1968, disponible en https://www.echr.coe.int/Documents/Convention_SPA.pdf (última consulta: 30 de enero de 2020).

123 Á. SOLANES CORELLA, "Contra la normalización de la ilegalidad: la protección judicial de los extranjeros frente a las expulsiones colectivas y las devoluciones «en caliente»", cit., p. 198.

${ }^{124}$ Rapport explicati du Protocole núm. 4 à la Convention de sauvegarde des Droits de l'Homme et des Libertés fondamentales, reconnaissant certains droits et libertés autres que ceux figurant déjà dans la Convention et dans le premier Protocole additionnel à la Convention, Estrasburgo, 16 de diciembre de 1963, pár. 31, disponible en https://rm.coe.int/16800c9330 (última consulta: 30 de enero de 2020). (La traducción me pertenece).

125 Á. SOLANES CORELLA, "Contra la normalización de la ilegalidad: la protección judicial de los extranjeros frente a las expulsiones colectivas y las devoluciones «en caliente»", cit., p. 198.

126 M. D. BOLLO AROCENA, Expulsión de extranjeros, derecho internacional y derecho europeo, cit., p. 63.

127 Un ejemplo que viola sistemáticamente este derecho a la tutela judicial efectiva es la "Operación Streamline" llevada a cabo en Estados Unidos. En estos casos, las personas migrantes son llevadas colectivamente ante un juez, quien -en pocos minutos- dicta la expulsión de todas las personas allí presentes. Vid. "La 
La aplicación del artículo 4 del Protocolo $n^{\circ} 4$ se realizará a todas las personas en contexto de movilidad, sin distinción de categorías migratorias o de protección jurídica que los rige. Es decir, se prohíbe el desarrollo de expulsiones colectivas cuando se trate de personas migrantes en el territorio o jurisdicción de un Estado, ya sea que se encuentren residiendo de manera regular, irregular, estén de tránsito, sean personas refugiadas, solicitantes de asilo 0 apátridas $^{128}$.

En el sistema de Naciones Unidas, la prohibición de las expulsiones colectivas está recogida en el artículo 22.1 de la Convención Internacional sobre la Protección de los Derechos de Todos los Trabajadores Migratorios y de sus Familiares ${ }^{129}$. Sin embargo, como se ha mencionado anteriormente, debido a que ningún Estado de la UE lo ha ratificado, no tiene un efecto vinculante ni un impacto jurídico en dicho contexto. Por otra parte, otros instrumentos regionales de protección de derechos humanos también prohíben las expulsiones colectivas en sus textos. En la CADH se encuentra establecida dicha prohibición en el artículo $22.9^{130}$, en la Carta Africana sobre Derechos Humanos y de los Pueblos se establece la prohibición de las expulsiones colectivas, a las que denomina "expulsión masiva", en el artículo $12.5^{131}$, y en la Carta Árabe de Derechos Humanos en el artículo 26.2 in fine ${ }^{132}$.

Por su parte, el Relator Especial sobre los derechos humanos de las personas migrantes ha expresado que "la prohibición de la expulsión colectiva de los no nacionales es un principio reconocido del derecho internacional consuetudinario"133. También el CAT ha hecho

«Operación Streamline» contra inmigrantes indocumentados desata alertas entre abogados y activistas", El Diario, 15 de abril de 2019, disponible en https://eldiariony.com/2019/04/15/la-operacion-streamline-contra-inmigrantes-

indocumentados-desata-alertas-entre-abogados-y-activistas/ (última consulta: 30 de enero de 2020).

128 Á. SOLANES CORELLA, "Contra la normalización de la ilegalidad: la protección judicial de los extranjeros frente a las expulsiones colectivas y las devoluciones «en caliente»", cit., p. 201.

129 "Artículo 22.1. Los trabajadores migratorios y sus familiares no podrán ser objeto de medidas de expulsión colectiva. Cada caso de expulsión será examinado y decidido individualmente". Convención Internacional sobre la Protección de los Derechos de Todos los Trabajadores Migratorios y de sus Familiares, cit.

130 "Artículo 22.9. Es prohibida la expulsión colectiva de extranjeros". Convención Americana sobre Derechos Humanos (Pacto de San José), cit.

131 "Artículo 12.5. La expulsión masiva de extranjeros estará prohibida. Expulsión masiva será aquella dirigida a un grupo nacional, racial, étnico o religioso". Carta Africana sobre Derechos Humanos y de los Pueblos, cit.

132 "Artículo 26.b. (...) La expulsión colectiva está prohibida en todos los casos". (La traducción me pertenece). Carta Árabe de Derechos Humanos, 22 de mayo de 2004, disponible en

https://www.right-to-education.org/sites/right-to-education.org/files/resource-

attachments/Revised_Arab_Charter_Human_Rights_2004_Em.pdf (última consulta: 30 de enero de 2020).

133 Consejo de Derechos Humanos de la Asamblea General de Naciones Unidas, Promoción y protección de todos los derechos humanos, civiles, políticos, 
mención sobre el asunto, en la Observación General Nº 4 de 2017, ya mencionada anteriormente, al sostener que "la expulsión colectiva, sin que se examinen objetivamente los casos individuales teniendo en cuenta el riesgo personal, debe considerarse una vulneración del principio de no devolución"134.

En el marco de Europa, el TEDH ha hecho un extenso análisis, y ha sentado jurisprudencia, sobre la prohibición de las expulsiones colectivas $y$, de manera complementaria, sobre la obligación de protección y respeto, por parte de los Estados, de garantizar el análisis individualizado de cada persona migrante pasible de expulsión.

La sentencia del TEDH, Hirsi Jamaa y otros contra Italia de 2012 es un precedente obligado -leading case- a la hora de analizar las expulsiones colectivas ${ }^{135}$. En este caso el TEDH condena a Italia por la expulsión colectiva de un grupo de personas migrantes de nacionalidad somalí y eritrea. Las embarcaciones en las que viajaban las personas migrantes procedían de Libia, y fueron interceptadas en alta mar, cerca de Lampedusa, por patrullas italianas y devueltas a Libia. En la concreción del hecho no se garantizó ni respetó que se llevaran a cabo los procedimientos de identificación personales por parte de las autoridades italianas. Por lo tanto, las personas migrantes no tuvieron acceso a asistencia letrada, interprete ni a los recursos efectivos con la orden de expulsión colectiva ${ }^{136}$.

Pese a que el Estado italiano argumentó que su actuación fue conforme a los acuerdos bilaterales celebrados con Libia para controlar la inmigración irregular y clandestina ${ }^{137}$, el TEDH condenó a

económicos, sociales y culturales, incluido el derecho al desarrollo. Informe del Relator Especial sobre los derechos humanos de los migrantes, Sr. Jorge Bustamante, cit., pár. 51 , nota a pie de página 36 .

134 Comité contra la Tortura de Naciones Unidas, Observación General No 4 (2017), relativa a la aplicación del artículo 3 de la Convención en el contexto del artículo 22, cit., pár. 13.

135 EL TEDH ha condenado, también, por la vulneración del artículo 4 del Protocolo n० 4 al CEDH en los siguientes casos: Čonka contra Bélgica, no 51564/99, del 5 de febrero de 2002; Georgia contra Rusia [GC], no 13255/07, del 3 de julio de 2014; Sharifi y otros contra Italia y Grecia, no 16643/09, del 21 de octubre de 2014; Shioshvili y otros contra Rusia, no 19356/07, del 20 de diciembre de 2016; Berdzenishvili y otros contra Rusia, no 14594/07, 14597/07, 14976/07, 14978/07, $15221 / 07,16369 / 07$ y $16706 / 07$, del 20 de diciembre de $2016 ;$ N. D. y N. T. contra España, no $8675 / 15$ y 8697/15 del 3 de octubre de 2017. En este último caso, el Estado español ha recurrido la sentencia del TEDH a la Gran Sala, que a la fecha ha escuchado a las partes y todavía no ha decidido sobre el tema (Ut supra nota 86). Asimismo, el TEDH tiene pendiente de resolución los asuntos Doumbe Nnabuchi contra España, n 19420/15; y Balde y Abel contra España, n²0351/17.

136 El TEDH sostiene explícitamente que "el personal a bordo de los buques militares no estaba capacitado para realizar entrevistas individuales y no recibió la asistencia de intérpretes o asesores legales". TEDH, Hirsi Jamaa y otros contra Italia, cit., pár. 185.

137 C. SOLER GARCÍA, "La prohibición de las expulsiones colectivas de extranjeros en la jurisprudencia del Tribunal europeo de Derechos Humanos: especial referencia 
Italia por la violación del artículo 4 del Protocolo $n^{\circ} 4$ por la consumación de la expulsión colectiva, el artículo $3 \mathrm{CEDH}$ por la exposición de las personas migrantes a tortura, tratos inhumanos o degradantes al ser devueltos a Libia, y el artículo 13 por la violación al derecho a un recurso efectivo.

Uno de los análisis más destacados que realiza el TEDH en la sentencia Hirsi Jamaa y otros contra Italia es el relacionado con la cuestión de la territorialidad y la jurisdicción. En el párrafo 74 de la sentencia destaca que "cuando un Estado, mediante agentes que operan fuera de su territorio, ejerce el control y autoridad y, por lo tanto, su jurisdicción, sobre un individuo, tal Estado tiene obligación, en virtud del artículo 1 , de garantizar a este individuo todos los derechos y libertades previstos en el Título I del Convenio que sean pertinentes en la situación del individuo"138. Por lo tanto, los casos de expulsión o devolución que se realicen más allá de frontera territorial nacional, pero que se lleven a cabo en espacios, zonas o situaciones en las que la persona se encuentra bajo el control y autoridad del Estado, forman parte de la jurisdicción del mismo aunque el hecho se suscite fuera del territorio estatal. Es decir que la aplicación territorial ha de entenderse en un sentido extensivo ${ }^{139}$.

En la Observación General No 31 sobre la naturaleza de la obligación general impuesta a los Estados Partes en el PIDCP, el Comité de Derechos Humanos afirma que "en virtud del párrafo 1 del artículo 2, los Estados Partes deben respetar y garantizar los derechos reconocidos en el Pacto a todas las personas que se encuentren en su territorio y a todas las que estén sujetas a su jurisdicción. Esto significa que un Estado Parte debe respetar y garantizar los derechos enunciados en el Pacto a toda persona que esté bajo la autoridad o el control efectivo del Estado Parte aunque no se encuentre en el territorio del Estado Parte"140. Igualmente, la Opinión Consultiva sobre la aplicación extraterritorial del principio de no devolución en virtud de las obligaciones contraídas por los Estados parte de la Convención de 1951 sobre el Estatuto de los Refugiados y su protocolo de 1967, estipula que "el criterio decisivo no es si tales personas se encuentran en el territorio del Estado sino, más bien, si se encuentran bajo el efectivo control y autoridad de ese Estado"141.

al caso de España", Revista General de Derecho Europeo, núm. 45, 2018, pp. 107160 , p. 154.

138 TEDH, Hirsi Jamaa y otros contra Italia, cit., pár. 74.

139 Á. SOLANES CORELLA, "Contra la normalización de la ilegalidad: la protección judicial de los extranjeros frente a las expulsiones colectivas y las devoluciones «en caliente»", cit., p. 208.

140 Comité de Derechos Humanos de Naciones Unidas, Observación General No 31 [80]: Naturaleza de la obligación jurídica general impuesta a los Estados Partes en el Pacto, cit., pár. 10.

141 Agencia de la ONU para los Refugiados (ACNUR), Opinión Consultiva sobre la aplicación extraterritorial de las obligaciones de no devolución en virtud de la Convención sobre el Estatuto de los Refugiados de 1951 y su Protocolo de 1967, Ginebra, 26 de enero de 2007, pár. 43, disponible en 
En ese sentido, el TEDH, en la sentencia mencionada, destacó que si el artículo 4 del Protocolo $n^{\circ} 4$ solamente se aplica a las expulsiones colectivas realizadas desde el territorio nacional, una parte significativa de los flujos migratorios contemporáneos quedarían desprotegidos ${ }^{142}$.

Por otra parte, es importante destacar la consideración del TEDH sobre el deber de los Estados de investigar sobre las condiciones a las que estarían expuestas las personas migrantes a las que pretende expulsar o devolver ${ }^{143}$, y refuerza el argumento sosteniendo que pese a que las personas no soliciten asilo formalmente, dicha situación no esgrime a los Estados con su obligación de proteger el artículo 3 del $\mathrm{CEDH}^{144}$.

Las expulsiones colectivas, pero también las remisiones a terceros Estados a partir de acuerdos de readmisión, sin realizar análisis individuales de la situación de cada persona, pero además sin tener en cuenta la situación de los países a los que se expulsan a las personas, y todo bajo el argumento de la "lucha contra la inmigración irregular", constituye una clara violación de derechos humanos.

\section{4.- LOS ACUERDOS DE READMISIÓN}

Una de las maneras de concretar el proceso de externalización del control migratorio es la firma de acuerdos de readmisión con países de origen y tránsito de las personas migrantes. Estos acuerdos se han convertido en uno de los ejes centrales de la política migratoria europea y se justifican en el marco de las relaciones exteriores del llamado "planteamiento global para prevenir y controlar la inmigración irregular"145.

Los acuerdos de readmisión pueden desarrollarse tanto a nivel bilateral como multilateral o comunitario. A continuación, se analizará, primero, el desarrollo de normativa de la UE en materia de expulsión, el cual permite desarrollar lo relativo a los convenios de la Unión con terceros países. $Y$, en segundo lugar, se realizará una aproximación al acuerdo bilateral entre España y Marruecos. Esa frontera, y la política migratoria desarrollada por ambos países,

https://www.acnur.org/fileadmin/Documentos/BDL/2009/7123.pdf

(última consulta: 30 de enero de 2020).

142 TEDH, Hirsi Jamaa y otros contra Italia, cit., pár. 177.

143 Incluso la CDI en su proyecto de artículo establece que: "Artículo 23: Obligación de no expulsar a un extranjero a un Estado en el que su vida estaría amenazada" y "Artículo 24: Obligación de no expulsar a un extranjero a un Estado en el que podría ser sometido a tortura 0 a tratos 0 penas crueles, inhumanos 0 degradantes". Comisión de Derecho Internacional, Asamblea General de Naciones Unidas, Informe de la Comisión de Derecho Internacional $66^{\circ}$ período de sesiones, cit.

144 TEDH, Hirsi Jamaa y otros contra Italia, cit., pár. 133.

145 N. ARENAS HIDALGO, "Los acuerdos europeos de readmisión de inmigrantes en situación irregular. Diez años de política europea de readmisión a debate", Cuadernos Europeos de Deusto, núm. 43, 2010, pp. 53-90, p. 54. 
tienen una particular importancia debido a su ubicación geográfica y al rol de España como "guardián de la UE".

\section{1.- Normativa de la Unión Europa relativa a migración y los convenios de la Unión Europea con terceros países}

La concepción de la Unión Europea como un espacio de libre circulación de personas tuvo como uno de sus resultados la redefinición y reestructuración del régimen fronterizo de cada uno de los países que lo integran. A partir de la firma del Acuerdo de Schengen en $1985^{146}$ se suprimieron las fronteras interiores entre los países que componen la Unión al tiempo que se fortalecieron las fronteras exteriores comunitarias ${ }^{147}$.

Desde la firma del Acuerdo y creación del "Espacio Schengen" se produce la "europeización de las políticas migratorias" con un enfoque securitista, promoviéndose el reforzamiento de los dispositivos de seguridad fronterizo ${ }^{148}$. Los motivos que justifican esta perspectiva, la cual pone el énfasis en el control de las fronteras exteriores, se basan en la protección del espacio de libre circulación y de seguridad comunitaria. Esta mirada ha contribuido $-y$ contribuyeal abordaje de la migración extracomunitaria como amenaza (a la seguridad, a la estabilidad política, a la cultura, a la identidad, a la economía, etc.).

En 1994 se produce la firma del Tratado de Maastricht, que representa otro acontecimiento importante en la incorporación del asunto migratorio a la agenda política de la UE. De acuerdo con este instrumento internacional, "se establecen estructuras formales para el desarrollo de los acuerdos en lo relativo a las migraciones internacionales con destino a la UE"149, incluyendo la unificación de la política de asilo y de la política de visados.

Por su parte, el Convenio de Dublín (I de 1990, II de 2003 y, el actualmente vigente, III de 2013) regula el sistema de asilo estableciendo cuál es el Estado miembro responsable del examen de las solicitudes de asilo. En este caso, el Acuerdo de Dublín III establece que "la persona que entre en territorio de la Unión y pretenda solicitar asilo debe hacerlo ante las autoridades del país al que acceda en primer lugar, de tal modo que, si no lo hace, y se

\footnotetext{
146 Los acuerdos firmados el 14 de junio de 1985 en Schengen (Luxemburgo) han implicado la supresión de las fronteras interiores de la Unión Europea. El objetivo ha sido crear un espacio de libre circulación y de seguridad para las para los ciudadanos y ciudadanas de los Estados miembros. Ese espacio es conocido como Espacio Schengen y cuenta con la cooperación de los Estados miembros.

147 A. PÉREZ CARAMÉS, "La evolución reciente de las políticas de control migratorio en España", cit., p. 145.

148 C. WIHTOL DE WENDEN, El fenómeno migratorio en el siglo XXI. Migrantes, refugiados y relaciones internacionales, cit., p. 45.

149 A. PÉREZ CARAMÉS, "La evolución reciente de las políticas de control migratorio en España", cit., p. 148.
} 
dirige al territorio de otro Estado miembro, este último tiene la facultad de trasladar al individuo al Estado considerado «responsable» de resolver la solicitud"150.

Las consecuencias a partir de los Convenios de Schengen y Dublín en cuestiones de migración y asilo son, por un lado, el reforzamiento de la seguridad de las fronteras, la creación de zonas de seguridad y el surgimiento de "Estados tapón"151, y, por el otro, la formación de un "cordón" de "supuestos terceros países seguros" alrededor de la UE en los cuales es posible solicitar asilo152.

Para la puesta en marcha de los objetivos planteados por los Convenios mencionados, la UE lleva adelante medidas decisorias. Una de ellas es la creación en 2004 de una Agencia Europea para la gestión de la cooperación operativa en las fronteras exteriores de los Estados miembros de la Unión Europea -FRONTEX-153. El objetivo de esta agencia policial de fronteras, en la que cooperan los Estados de la UE y que tiene sede en Varsovia, ha sido coordinar la vigilancia de las fronteras de los Estados europeos, utilizando para ello sofisticados medios de control. En 2016, el Reglamento 2016/1624 ha modificado su nombre por el de Agencia Europea de la Guardia de Fronteras y Costas (manteniendo la abreviatura FRONTEX) y ha ampliado sus funciones, tanto en materia de control de fronteras como de retorno ${ }^{154}$. Esta agencia representa una de las formas de externalización del control migratorio que ejerce la UE, ya que el patrullaje y control lo realiza incluso más allá de las fronteras exteriores del espacio Schengen.

Por otra parte, la adopción de la Directiva 2008/115/CE ${ }^{155}$, conocida como Directiva sobre retorno o "Directiva de la vergüenza",

150 M. D. BOLLO AROCENA, Expulsión de extranjeros, derecho internacional y derecho europeo, cit., p. 46. Vid. Capítulo III. Criterios de determinación del Estado miembro responsable, artículos 7 a 15 del Reglamento (UE) 604/2013 del Parlamento Europeo y del Consejo, de 26 de junio de 2013 por el que se establecen los criterios y mecanismos de determinación del Estado miembro responsable del examen de una solicitud de asilo presentada en uno de los Estados miembros por un nacional de un tercer país o un apátrida (texto refundido), disponible en https://eur-lex.europa.eu/legal-content/ES/TXT/?uri=CELEX\%3A32013R0604

(última consulta: 30 de enero de 2020).

${ }^{151}$ C. WIHTOL DE WENDEN, El fenómeno migratorio en el siglo XXI. Migrantes, refugiados y relaciones internacionales, cit., p. 61.

152 S. MEZZADRA y B. NEILSON, La frontera como método, cit. 172.

153 Reglamento (CE) 2007/2004 del Consejo, de 26 de octubre de 2004, por el que se crea una Agencia Europea para la gestión de la cooperación operativa en las fronteras exteriores de los Estados miembros de la Unión Europea, disponible en https://eur-lex.europa.eu/legal-content/ES/ALL/?uri=CELEX\%3A32004R2007 (última consulta: 30 de enero de 2020).

154 F. VACAS FERNÁNDEZ, EI Derecho Migratorio, Internacional y Europeo, como Límite desde los Derechos Humanos a la Discrecionalidad de los Estados en Materia Migratoria, cit., pp. 172-173.

155 Directiva 2008/115/CE del Parlamento Europeo y del Consejo, de 16 de diciembre de 2008, relativa a normas y procedimientos en los Estados miembros para el retorno de los nacionales de terceros países en situación irregular, disponible en 
es sustancial para la política de control migratorio de la UE respecto a los retornos forzosos y a la detención administrativa de personas migrantes.

Conjuntamente, la UE desarrolla acuerdos de cooperación internacional con países de origen, residencia o tránsito de las personas migrantes que intentan llegar a Europa para realizar los retornos y con la "supuesta" finalidad de limitar la migración irregular ${ }^{156}$. Mediante estos acuerdos, los países de origen $\mathrm{y} / \mathrm{o}$ tránsito de las personas migrantes refuerzan sus sistemas de control migratorio, y como contraprestación, los países de la UE ponen en marcha políticas de desarrollo, acuerdos económicos o acuerdos de flexibilización de entrada y estancia para los nacionales de esos países de origen y/o tránsito ${ }^{157}$. Con relación a lo último, el Relator Especial sobre los derechos humanos de los migrantes manifestó con preocupación que "esos acuerdos se están utilizando cada vez más como instrumento de negociación por la Unión Europea y los Estados firmantes -con fuertes incentivos para ambas partes, incluida la liberalización de visados o los acuerdos de facilitación en el caso de los países firmantes y la readmisión en el caso de la Unión Europea, [y] en ninguna de esas consideraciones se incluyen de forma automática los derechos humanos"158.

https://eur-lex.europa.eu/legal-content/ES/TXT/?uri=CELEX\%3A32008L0115 (última consulta: 30 de enero de 2020).

156 Por un lado, el Tratado de Funcionamiento de la Unión Europea reconoce la facultad para llevar a cabo estos acuerdos y lo establece en el artículo 79.3: "La Unión podrá celebrar con terceros países acuerdos para la readmisión, en sus países de origen o de procedencia, de nacionales de terceros países que no cumplan o que hayan dejado de cumplir las condiciones de entrada, presencia o residencia en el territorio de uno de los Estados miembros". Versión consolidada del Tratado de Funcionamiento de la Unión Europea, cit. Por otro lado, la cumbre de los ministros del Consejo Europeo celebrado en la ciudad de Sevilla en 2002, que tuvo como prioridad de la política común la lucha contra la inmigración irregular, estableció en las conclusiones que "el Consejo Europeo considera que la lucha contra la inmigración ilegal requiere un esfuerzo más intenso por parte de la Unión Europea y un planteamiento específico del fenómeno, utilizando todos los instrumentos oportunos en las relaciones exteriores de la Unión Europea. (...) El Consejo Europeo insta a que se incluya una cláusula sobre gestión común de los flujos migratorios y sobre la readmisión obligatoria en caso de inmigración ilegal en todo futuro acuerdo de cooperación, de asociación o equivalente que la Unión Europea o la Comunidad Europea celebre con cualquier país". Consejo de la Unión Europea, Consejo Europeo de Sevilla, 21 y 22 de junio. Conclusiones de la presidencia, 24 de octubre de 2002, 13463/02, pár. 33, disponible en https://www.consilium.europa.eu/media/20922/72639.pdf (última consulta: 30 de enero de 2020).

157 C. WIHTOL DE WENDEN, El fenómeno migratorio en el siglo XXI. Migrantes, refugiados y relaciones internacionales, cit., p. 184.

158 Consejo de Derechos Humanos de la Asamblea General de Naciones Unidas, Informe del Relator Especial sobre los derechos humanos de los migrantes, François Crépeau. Estudio regional: administración de las fronteras periféricas de la Unión Europea y sus repercusiones sobre los derechos humanos de los migrantes, cit., pár. 64. 
Tal como remarca Vacas Fernández, existe una amplia variedad de acuerdos multilaterales o bilaterales en materia migratoria, y eso responde a la complejidad del fenómeno migratorio. Si bien la mayoría de los acuerdos que celebra la UE con terceros Estados están relacionados con la reconducción a la frontera y la readmisión de migrantes irregulares a terceros Estados y con el establecimiento de mayores controles fronterizos, también se celebran acuerdos de asociación y cooperación relacionados con la implementación de procesos de regulación de migrantes irregulares 0 con la reglamentación sobre entrada, permanencia y estatus jurídico de las personas migrantes provenientes de esos Estados con los que se firma el acuerdo ${ }^{159}$.

Sin embargo, la lógica securitaria imperante en las políticas de control migratorio se traduce en un mayor predominio de los convenios relacionados con el financiamiento de centros de detención fuera de los países de destino, el control de las fronteras y los acuerdos de readmisión de la UE con terceros Estados. Estos acuerdos pueden distinguirse, a grandes rasgos, en tres:

En primer lugar, los acuerdos de "repatriación" son aquellos por los cuales los Estados partes se comprometen a admitir en sus territorios a personas que sean sus nacionales y que se encuentren en situación migratoria irregular en otro de los Estados parte ${ }^{160}$. De acuerdo con el artículo 13.2 de la $D^{2} D^{161}$ y el artículo 12.4 de PIDCP ${ }^{162}$, las personas tienen el derecho de ingresar a su propio país, y por corolario, los Estados la obligación de readmitir a sus propios nacionales ${ }^{163}$.

En segundo lugar, los acuerdos de "readmisión" propiamente dichos, por los cuales los Estados partes se comprometen a admitir en su territorio a personas no nacionales de sus Estados pero que han transitado por él. Es decir que se comprometen a admitir a personas que debido al trayecto de su ruta migratoria atravesaron dicho Estado antes de llegar al Estado donde se encuentran en situación migratoria irregular ${ }^{164}$. En este caso, si bien no existe una obligación establecida en el Derecho internacional como sucede con la admisión de los

\footnotetext{
159 F. VACAS FERNÁNDEZ, Los tratados bilaterales adoptados por España para regular y ordenar los flujos migratorios. Contexto, marco jurídico y contenido, Dykinson, Madrid, 2007, pp. 156 y 181-185.

160 Ibídem, pp. 192-194.

161 Ut Supra nota 17.

162 "Artículo 12.4. Nadie podrá ser arbitrariamente privado del derecho a entrar en su propio país". Pacto Internacional de Derechos Civiles y Políticos, cit.

163 N. ARENAS HIDALGO, "Los acuerdos europeos de readmisión de inmigrantes en situación irregular. Diez años de política europea de readmisión a debate", cit., p. 61.

164 F. VACAS FERNÁNDEZ, Los tratados bilaterales adoptados por España para regular y ordenar los flujos migratorios. Contexto, marco jurídico y contenido, cit., p. 197.
} 
propios nacionales, se deduce de las obligaciones contraídas por la firma del convenio o acuerdo ${ }^{165}$.

En último lugar, los acuerdos de "tránsito", los cuales refieren a la posibilidad de que una persona transite por un Estado parte del acuerdo a los fines de llegar a otro Estado de destino, que normalmente suele ser el Estado del que la persona es nacional, y cuya procedencia es un Estado de la UE donde se encuentra en situación migratoria irregular ${ }^{166}$.

Por lo tanto, la política de retorno requiere de la colaboración de los Estados de origen y tránsito (y también de los intereses y las necesidades que tengan), ya que la devolución de las personas migrantes en situación migratoria irregular a esos países sería imposible, tanto desde una perspectiva jurídica como práctica, de no ser por la aceptación y la firma de los convenios que le generan obligaciones y responsabilidades ${ }^{167}$.

Los acuerdos de readmisión pueden desarrollarse paralela, y en muchos casos complementariamente, a nivel comunitario como a nivel nacional. A nivel comunitario-multilateral (es decir, aquellos firmados por la UE y los Estados miembros) existe la posibilidad de introducir "cláusulas de readmisión" en acuerdos de asociación y cooperación ya firmados, como de negociar y concluir acuerdos de readmisión propiamente dicho ${ }^{168}$.

Asimismo, cada Estado miembro de la UE tiene la competencia para firmar y negociar sus propios acuerdos bilaterales ${ }^{169}$. Estos acuerdos de readmisión de personas con terceros Estados se negocian en función de las necesidades propias de cada Estado miembro ${ }^{170}$, y son, en la actualidad, uno de los principales

165 N. ARENAS HIDALGO, "Los acuerdos europeos de readmisión de inmigrantes en situación irregular. Diez años de política europea de readmisión a debate", cit., p. 62.

166 F. VACAS FERNÁNDEZ, Los tratados bilaterales adoptados por España para regular y ordenar los flujos migratorios. Contexto, marco jurídico y contenido, cit., p. 202, y F. VACAS FERNÁNDEZ, El Derecho Migratorio, Internacional y Europeo, como Límite desde los Derechos Humanos a la Discrecionalidad de los Estados en Materia Migratoria, cit., p. 230.

167 N. ARENAS HIDALGO, "El acuerdo europeo de readmisión de inmigrantes en situación irregular con Pakistán. Punto de inflexión o huida hacia delante", Revista General de Derecho Europeo, núm. 24, 2011, pp. 1-40, p. 2.

168 ARENAS HIDALGO, N., "Los acuerdos europeos de readmisión de inmigrantes en situación irregular. Diez años de política europea de readmisión a debate", cit., p. 63.

169 F. VACAS FERNÁNDEZ, Los tratados bilaterales adoptados por España para regular y ordenar los flujos migratorios. Contexto, marco jurídico y contenido, cit., p. 160.

170 N. ARENAS HIDALGO, "Los acuerdos europeos de readmisión de inmigrantes en situación irregular. Diez años de política europea de readmisión a debate", cit., p. 63. 
instrumentos con los que cuentan los Estados de la UE para gestionar sus políticas migratorias ${ }^{171}$.

A pesar de ello, y tal como estableció el TEDH en la ya mencionada sentencia Hirsi Jamaa y otros contra Italia, los acuerdos bilaterales no eximen a los Estados de cumplir con las normas del Derecho internacional de los derechos humanos, y en este caso en particular los artículos del CEDH. El TEDH afirmó que, aunque el tercer Estado haya contraído obligaciones internacionales de protección de los derechos fundamentales, lo relevante a tener en cuenta es la práctica efectiva de ese tercer Estado respecto al trato de las personas migrantes readmitidas ${ }^{172}$. El respeto y garantía de los derechos humanos de las personas migrantes debe anteponerse y regir la aplicación de este tipo de acuerdos ${ }^{173}$.

Por último, y para mencionar un ejemplo de acuerdo de readmisión, que vulnera derechos fundamentales internacionalmente reconocidos, bajo la lógica de la externalización del control de las fronteras y el control de los flujos migratorios, cabe recordar la Declaración de la UE-Turquía firmada el 18 de marzo de $2016^{174}$. Dicho acuerdo le "otorga a Turquía una posición protagonista en el control de las fronteras exteriores de la UE y en el control de las rutas migratorias a través del mediterráneo oriental [con el fin de] acabar con los desplazamientos masivos de personas hacia las islas griegas"175. El acuerdo se basaba en el pago de unos 6.000 millones

171 F. VACAS FERNÁNDEZ, Los tratados bilaterales adoptados por España para regular y ordenar los flujos migratorios. Contexto, marco jurídico y contenido, cit., p. 239.

172 TEDH, Hirsi Jamaa y otros contra Italia, cit., pár. 128. En estos casos rige el principio internacional de no devolución y también los artículos 17, 23 y 24 del proyecto de artículos sobre la expulsión de extranjeros de la CDI. "Artículo 17. Prohibición de la tortura y de los tratos o penas crueles, inhumanos o degradantes. El Estado expulsor no someterá a un extranjero objeto de expulsión a tortura ni a tratos o penas crueles, inhumanos o degradantes". Artículos 23 y 24 anteriormente citados. Comisión de Derecho Internacional, Asamblea General de Naciones Unidas, Informe de la Comisión de Derecho Internacional $66^{\circ}$ período de sesiones, cit.

173 S. TORRECUADRADA GARCÍA-LOZANO, "Migraciones en masa en el derecho internacional" en N. CORNAGO, J. L. DE CASTRO y L. MOURE (eds.), Repensar la Unión Europea: Gobernanza, seguridad, mercado interior y ciudadanía. XXVII Jornadas AEPDIRI, Tirant lo Blanch, Valencia, 2019, pp. 135-151, p. 141.

174 Vid. P. AGUELO NAVARRO y H. V. GRANERO, "La Declaración UE-Turquía de 18 de marzo de 2016. Un fantasma que recorre Europa", Revista de derecho migratorio y extranjería, núm. 45, 2017, pp. 239-290. En la misma línea, Vid., en la noticia del diario Público, sobre los acuerdos alcanzados en la cumbre UE-África en la Valeta (Malta), particularmente con Libia, "Europa destina 130 millones a convertir Libia en su nuevo «muro» antiinmigración", Público, 8 de febrero de 2017, disponible en https://www.publico.es/internacional/europa-destina-130-milloneslibia.html (última consulta: 30 de enero de 2020).

175 J. URBANEJA CILLÁN, "La declaración UE-Turquía, de 18 de marzo de 2016: ¿Un acuerdo de la Unión Europea?", en N. CORNAGO, J. L. DE CASTRO y L. MOURE (eds.), Repensar la Unión Europea: Gobernanza, seguridad, mercado interior y ciudadanía. XXVII Jornadas AEPDIRI, Tirant lo Blanch, Valencia, 2019, pp. 323-338, p. 325. 
de euros a Turquía por parte de la UE, la posibilidad de liberar el sistema de visados para las personas nacionales de Turquía y la promesa de un diálogo y negociación de la adhesión de Turquía a la UE ${ }^{176}$. A cambio, Turquía se comprometió a "aceptar la rápida devolución de las personas migrantes en situación irregular [mal llamadas ilegales en la Declaración] y también de las personas llegadas a Grecia desde su territorio cuyas solicitudes de asilo hayan sido declaradas inadmisibles"177. Además, "por cada ciudadano sirio retornado a Turquía, la UE se comprometió a reasentar en su territorio un ciudadano sirio que se encuentre en Turquía, dando preferencia a aquellos que no hayan tratado de entrar ilegalmente en la Unión Europea. Es lo que se conoce como one in one out o uno por uno"178. Conforme con De Lucas, esta Declaración implica el vaciamiento del derecho de asilo, por varias razones: "se vacía de contenido el propio derecho de asilo como un derecho individual. Se obstaculiza el procedimiento legal de solicitud de asilo y se viola la prohibición de expulsiones colectivas"179. Asimismo, se pone en riesgo la protección del principio de no devolución, y vulnera el Convenio de Ginebra y el Derecho Europeo.

Aunque la Declaración se haya firmado bajo el argumento de que la UE considera a Turquía como un "tercer país seguro", el análisis legal y fáctico de la situación de desprotección de los derechos fundamentales en ese país da cuenta de lo contrario ${ }^{180}$.

\footnotetext{
176 Para De Lucas este acuerdo convierte a las personas migrantes, solicitantes de asilo y refugiados en "objeto de trueque geopolítico entre la UE y Turquía". Vid. J. DE LUCAS, "Refugiados como «moneda de cambio». Sobre el acuerdo entre la Unión Europea y Turquía de 18 de marzo de 2016", Anuario de Derechos Humanos, núm. 12, 2016, pp. 17-32, p. 27.

177 Comisión Española de Ayuda al Refugiado (CEAR), Informe 2016: Las personas refugiadas en España y Europa, p. 50, disponible en https://www.cear.es/wpcontent/uploads/2016/06/Informe_CEAR_2016.pdf (última consulta: 30 de enero de 2020).

178 M. D. BOLLO AROCENA, Expulsión de extranjeros, derecho internacional y derecho europeo, cit., p. 141.

179 J. DE LUCAS, "Refugiados como «moneda de cambio». Sobre el acuerdo entre la Unión Europea y Turquía de 18 de marzo de 2016", cit., p. 26.

180 La Directiva 2013/32/UE determina cuáles son las características que debe cumplir un país para ser considerado "tercer país seguro" o "tercer país seguro europeo" en los artículos 38 y 39 respectivamente. El artículo 38 estable: "1. Los Estados miembros solo podrán aplicar el concepto de tercer país seguro cuando las autoridades competentes tengan la certeza de que el solicitante de protección internacional recibirá en el tercer país un trato conforme a los siguientes principios: a) su vida o su libertad no están amenazadas por razón de raza, religión, nacionalidad, pertenencia a un grupo social particular u opinión política; b) no hay riesgo de daños graves tal como se definen en la Directiva 2011/95/UE; c) se respeta el principio de no devolución de conformidad con la Convención de Ginebra; d) se respeta la prohibición de expulsión en caso de violación del derecho de no ser sometido a torturas ni a tratos crueles, inhumanos o degradantes, establecido en el Derecho internacional; e) existe la posibilidad de solicitar el estatuto de refugiado $y$, en caso de ser refugiado, recibir protección con arreglo a la Convención de Ginebra (...)". Directiva 2013/32/UE del Parlamento Europeo y del Consejo, de 26
} 
Nuevamente es aplicable lo establecido por el TEDH en la sentencia Hirsi Jamaa y otros contra Italia, párrafo 128 , en la que establece que lo relevante a tener en cuenta es la práctica efectiva de ese tercer Estado respecto al trato de las personas migrantes readmitidas.

\section{2.- Convenios bilaterales: España-Marruecos}

España ha seguido las políticas de control migratorio desarrolladas por la Unión Europea, principalmente la externalización de la vigilancia fronteriza, a partir de su "incorporación al espacio Schengen, la ratificación del Convenio de Dublín y, posteriormente, con la aceptación de las conclusiones de la cumbre de Tampere y la firma del Tratado de Ámsterdam (1999)"181.

Desde su transformación como país de destino, España ha firmado una gran cantidad de acuerdos bilaterales en materia migratoria. En 1992 adopta el primer acuerdo de readmisión con Marruecos ${ }^{182}$.

de junio de 2013, sobre procedimientos comunes para la concesión o la retirada de la protección internacional, disponible en https://eur-lex.europa.eu/legalcontent/es/TXT/?uri=celex:32013L0032 (última consulta: 30 de enero de 2020). De acuerdo a los informes emitidos por organizaciones de derechos humanos, Turquía no es un país seguro y vulnera los tratados internacionales. Vid. Amnistía Internacional, Turquía: Las devoluciones ilegales y en masa de personas refugiadas sirias ponen de manifiesto los fatídicos defectos del acuerdo entre la UE y Turquía, $1^{\circ}$ de abril de 2016, disponible en

https://www.amnesty.org/es/latest/news/2016/04/turkey-illegal-mass-returns-ofsyrian-refugees-expose-fatal-flaws-in-eu-turkey-deal/ (última consulta: 30 de enero de 2020); Comisión Española de Ayuda al Refugiado (CEAR), Lesbos, "zona cero" del derecho de asilo, 2016, pp. 29-35, disponible en https://www.cear.es/wpcontent/uploads/2016/04/Informe-Mision-Lesbos-marzo2016.pdf (última consulta: 30 de enero de 2020); Comisión Española de Ayuda al Refugiado (CEAR), Informe al Comisario Europeo de Derechos Humanos relativo al Acuerdo Unión EuropeaTurquía adoptado el 18 de marzo de 2016 y las consecuencias de su aplicación en los derechos de las personas migrantes y refugiadas, 2016, disponible en https://www.cear.es/wp-content/uploads/2016/05/INFORME-COMISARIO-

EUROPEO-DDHH.pdf (última consulta: 30 de enero de 2020). Por su parte, el artículo 39 de la Directiva 2013/32/UE mencionada establece, en uno de sus incisos, que un tercer país sólo podrá ser considerado "tercer país seguro europeo" si ha ratificado la Convención de Ginebra sin restricciones geográficas y observa sus disposiciones. En este caso, si bien Turquía ha ratificado la Convención de Ginebra de 1951, no lo ha hecho respecto al Protocolo de Nueva York de 1967 sobre la eliminación de la restricción temporal y geográfica de la Convención. Vid. D. LÓPEZ GUERRA, Acuerdo UE-Turquía: refugiados sin ley, 2016, disponible en https://ctxt.es/es/20160420/Politica/5505/acuerdo-UE-Turquia-refugiados-

inmigracion-grecia-siria-vulneracion-derechos-derecho-asilo.htm (última consulta: 30 de enero de 2020).

${ }^{181}$ A. PÉREZ CARAMÉS, "La evolución reciente de las políticas de control migratorio en España", cit., p. 180.

182 F. VACAS FERNÁNDEZ, Los tratados bilaterales adoptados por España para regular y ordenar los flujos migratorios. Contexto, marco jurídico y contenido, cit., p. 187. 
El acuerdo bilateral entre España y Marruecos relativo a la circulación de personas, el tránsito y la readmisión de personas extranjeras entradas ilegalmente se firma en Madrid en $1992^{183}$ pero su entrada definitiva en vigor se produjo en $2012^{184}$. Este permite que la Guardia Civil "devuelva" inmediatamente a Marruecos a las personas migrantes -aunque no necesariamente nacionales de Marruecos- interceptadas en la frontera -las vallas- 0 sus cercanías $^{185}$.

Este acuerdo, como ningún otro, puede sustituir los derechos y garantías reconocidos en la legislación nacional e internacional. El mismo debería aplicarse una vez que se ha dictado una orden de expulsión o devolución conforme a la ley y con el respeto de las garantías procesales correspondientes. Incluso, el propio acuerdo establece una serie de obligaciones mutuas para la ejecución de las "admisiones" o "devoluciones", por lo que cualquier acción de hecho es absolutamente contraria a derecho ${ }^{186}$.

El gobierno de España, siguiendo con la lógica securitaria y de "xenofobia institucional" de la UE, intenta legitimar el blindaje de fronteras amparándose en la defensa contra la amenaza a la seguridad, la economía y la identidad nacional que generan las migraciones. Para ello acude, por un lado, a la puesta en práctica de este tipo de políticas de externalización del control migratorio, que manifiesta una de sus caras en los acuerdos bilaterales de cooperación, con Estados de dudosa defensa y protección de los derechos humanos. Por otro lado, intenta legitimar el recorte de derechos y garantías procesales y reglamentarizar políticas y prácticas ilegales, convirtiendo de este modo a la normativa migratoria en un derecho de excepción ${ }^{187}$. El ejemplo más claro de ello es la adopción de la LO 4/2015 de protección de la seguridad ciudadana, "Ley Mordaza", modificando la LO 4/2000 sobre derechos

183 Acuerdo entre el Reino de España y el Reino de Marruecos relativo a la circulación de personas, el tránsito y la readmisión de extranjeros entrados ilegalmente, firmado en Madrid el 13 de febrero de 1992, de 25 de abril de 1992 (BOE núm. 100, del 25 de abril de 1992), disponible en https://www.boe.es/diario_boe/txt.php?id=BOE-A-1992-8976 (última consulta: 30 de enero de 2020).

184 Entrada en vigor del Acuerdo entre el Reino de España y el Reino de Marruecos relativo a la circulación de personas, el tránsito y la readmisión de extranjeros entrados ilegalmente, hecho en Madrid el 13 de febrero, del 13 de diciembre de 2012 (BOE núm. 299, del 13 diciembre de 2012), disponible en https://www.boe.es/diario_boe/txt.php?id=BOE-A-2012-15050 (última consulta: 30 de enero de 2020).

185 S. BECERRIL, "Actuaciones de la Defensoría del Pueblo español en torno a los DDHH y la situación de la valla en Melilla" en J. L. VILLENA HIGUERAS (coord.), Derechos humanos y justicia universal en la frontera sur, Universidad de Granada, Granada, 2016, pp. 61-76, p. 70.

186 M. MARTÍNEZ ESCAMILLA, "Devoluciones en caliente. Un análisis jurídico", cit., p. 89.

187 J. DE LUCAS, Mediterráneo: El naufragio de Europa, cit., p. 105. 
y libertades de los extranjeros en España y su integración ${ }^{188}$, que reglamenta el régimen de rechazos en frontera de las personas migrantes que llegan a Ceuta y Melilla.

Las prácticas y políticas europeas de readmisión, y por lo tanto también las españolas, son una más de las formas de materializar la "securitización" y la externalización de las políticas de control migratorio, que en la mayoría de los casos menoscaban los derechos fundamentales de las personas migrantes y vulneran las obligaciones internacionales en materia de derechos humanos contraídas por los Estados constitucionales de derecho ${ }^{189}$.

En conclusión, los procesos de "securitización" de las políticas migratorias están cobrando cada vez más intensidad y están permeando las distintas políticas de control migratorio. Las expulsiones, y específicamente, las expulsiones colectivas, son una muestra de ello. Estas últimas - un fenómeno que ha ido adquiriendo presencia- ponen de manifiesto la vulneración de una serie de derechos fundamentales como la tutela judicial efectiva y el debido proceso, el principio de no discriminación y la igual protección de la ley, el principio de no devolución y el respecto por la vida, la dignidad y la integridad física de las personas. Como contrapunto, la garantía del principio de no devolución se ha convertido en el pilar para la protección de los derechos fundamentales de las personas en procesos de movilidad humana, ya que implica un límite en la soberanía de los Estados para establecer las condiciones de admisión y permanencia de personas migrantes en su territorio.

En el caso particular analizado, la respuesta de la Unión Europa frente a la gestión de las migraciones está orientada a la lucha contra la migración irregular y para ello aplica políticas securitarias y de externalización del control. En esta cruzada, construida mediática y políticamente, contra el "enemigo" externo que "supuestamente" amenaza a la seguridad, la estabilidad política, la cultura, la identidad, la economía, desconoce y vulnera los derechos fundamentales de las personas migrantes y obligaciones internacionales contraídas. La aplicación de los diversos mecanismos de control, con una lógica más cercana a la seguridad que a la protección de derechos humanos, ha tenido como principal consecuencia el incremento de la migración por vías irregulares. Los efectos que genera el desarrollo de una migración irregular se evidencian en el aumento de personas que mueren en el tránsito debido a la peligrosidad y precariedad de las rutas clandestinas.

188 Ley Orgánica 4/2000, del 11 de enero, sobre derechos y libertades de los extranjeros en España y su integración social (BOE núm. 10, del 12 de enero de 2000), disponible en https://www.boe.es/buscar/doc.php?id=BOE-A-2000-544 (última consulta: 30 de enero de 2020).

189 N. ARENAS HIDALGO, "Los acuerdos europeos de readmisión de inmigrantes en situación irregular. Diez años de política europea de readmisión a debate", cit., p. 89. 
Una de las formas de materializar la externalización del control migratorio es la implicancia de terceros países, de tránsito y de origen, en el control de los flujos migratorios a partir de los acuerdos de readmisión. Estos acuerdos transforman a las personas migrantes en "objetos de trueque geopolítico", en palabras de Javier de Lucas, ya que implican la aceptación de personas por parte de los terceros países a cambio de políticas económicas, de desarrollo o beneficios políticos.

Debido a la ubicación geográfica de sus fronteras, España se ha convertido en uno de los "guardianes de la UE" contra la inmigración, y así lo ha plasmado con la puesta en práctica y la regulación normativa de las devoluciones en caliente.

\section{5.- CONCLUSIONES}

1. Si en el ejercicio de su potestad soberana, los Estados aplican políticas migratorias arbitrarias y desproporcionadas, este accionar tiene un especial menoscabo en los derechos de un grupo determinado de la población: las personas migrantes.

2. Bajo la retórica de la seguridad nacional y la soberanía del Estado, el aparato burocrático estatal busca validar la aplicación de las políticas de recorte de libertades y garantías individuales. El recrudecimiento en los mecanismos de control migratorio y su lógica securitaria se visibiliza en prácticas y políticas como: las detenciones administrativas; la aplicación del derecho penal para las infracciones migratorias; las deportaciones; los rechazos en frontera; las redadas en lugares de trabajo, domicilios particulares y espacios públicos y la restricción en el acceso a derechos. Incluso, se agudiza la situación por la completa ausencia de garantías elementales del debido proceso en el marco de estos procedimientos. Entre las violaciones a las garantías del debido proceso más recurrentes se pueden mencionar: la falta de representación legal y de traductor; la inexistencia de información detallada; la imposibilidad de recurrir administrativamente o judicialmente las decisiones; la ausencia de individualidad en los procesos; la falta de autoridad competente que dictamine la medida; el incumplimiento de la aplicación de los principios de proporcionalidad y motivación suficiente en las decisiones y la omisión de atención médica necesaria y de otros derechos fundamentales.

3. Es necesario, entonces, fortalecer la protección de las garantías del debido proceso que constituyen instrumentos claves para la garantía de los derechos de las personas migrantes, y condenar a los Estados que tomen medidas contrarias al derecho internacional de los derechos humanos.

4. Los procesos de securitización de las políticas migratorias están cobrando cada vez más intensidad y están permeando las distintas políticas de control migratorio. Las expulsiones, y específicamente, las expulsiones colectivas, son una muestra de ello. 
5. Las expulsiones colectivas -fenómeno que ha ido adquiriendo presencia- ponen de manifiesto la vulneración de una serie de derechos fundamentales como la tutela judicial efectiva y el debido proceso, el principio de no discriminación y la igual protección de la ley, el principio de no devolución y el respecto por la vida, la dignidad y la integridad física de las personas.

6. La garantía del principio de no devolución se ha convertido en el pilar para la protección de los derechos fundamentales de las personas en procesos de movilidad humana, ya que implica un límite en la soberanía de los Estados de establecer las condiciones de admisión y permanencia de personas migrantes en su territorio.

7. En el caso particular, la respuesta de la Unión Europa frente a la gestión de las migraciones está orientada a la lucha contra la migración irregular y para ello aplica políticas securitarias y de externalización del control. En esta cruzada, construida mediática y políticamente, contra el "enemigo" externo que "supuestamente" amenaza a la seguridad, a la estabilidad política, a la cultura, a la identidad, a la economía, desconoce y vulnera los derechos fundamentales de las personas migrantes y obligaciones internacionales contraídas.

8. La aplicación de los diversos mecanismos de control con una lógica más cercana a la seguridad que a la protección de derechos humanos, ha tenido como principal consecuencia el incremento de la migración por vías irregular. Los efectos que genera el desarrollo de una migración irregular se evidencian en el aumento de personas que mueren en el tránsito migratorio debido a la peligrosidad y precariedad de las rutas clandestinas.

9. Una de las formas de materializar la externalización del control migratorio es la implicancia de terceros países, de tránsito y de origen, en el control de los flujos migratorio a partir de los acuerdos de readmisión. Estos acuerdos transforman a las personas migrantes en "objetos de trueque geopolítico", en palabras de Javier de Lucas, ya que implican la aceptación de personas por parte de los terceros países a cambio de políticas económicas, de desarrollo o beneficios políticos. Sin embargo, mientras continúen las causas estructurales por las cuales las personas tienen que salir de sus países de origen y persistan las vejaciones a sus derechos en los países de tránsito, estas no dejarán de migrar. Ni las fronteras amuralladas, cada vez más largas y cada vez más altas, ni las policías más represivas, ni las sociedades más xenófobas, ni las rutas ni los mares más peligrosos, ni los acuerdos más consolidados, evitarán que busquen -a sabiendas de arriesgar su vida que es lo único que les queda- protección y un lugar donde poder vivir.

10. Las expulsiones colectivas, pero también las remisiones a tercer Estados a partir de acuerdos de readmisión, sin realizar análisis individuales de la situación de cada persona, pero además sin tener en cuenta la situación de los países a los que se expulsan a las 
personas, y todo bajo el argumento de la "lucha contra la inmigración irregular", constituye una clara violación de derechos humanos.

11. Es menester hacer énfasis que desde una perspectiva de derechos humanos mientras mayor sea el grado de reconocimiento y de realización efectiva de los derechos de las personas migrantes, y particularmente el relacionado a las garantías de debido proceso en los procedimientos migratorios, más se reduce la situación de vulnerabilidad en la que se encuentran y más se amplían las oportunidades para la protección efectiva de sus derechos. Y, por ende, seremos parte de sociedades con un Estado de Derecho más fortalecido, más democráticas y representativas.

\section{6.- REFERENCIAS}

\section{1.- Bibliografía}

A. FERNÁNDEZ PÉREZ, "Estado del bienestar y contradicciones en la ordenación de los flujos migratorios" en S. TORRES BERNÁRDEZ, J. C. FERNÁNDEZ ROZAS, C. FERNÁNDEZ de CASADEVANTE ROMANÍ, J. QUEL LÓPEZ y A. G. LÓPEZ MARTÍN (coords.), El derecho internacional en el mundo multipolar del siglo XXI. Obra Homenaje al profesor Luis Ignacio Sánchez Rodríguez, Iprolex, Madrid, 2013, pp. 791-823.

A. PERÉZ CARAMÉS, "La evolución reciente de las políticas de control migratorios en España" en A. IZQUIERDO y W. A. CORNELIUS (eds.), Políticas de control migratorio. Estudio comparado de España y EE.UU., Bellaterra, Barcelona, 2012, pp. 143-211.

Á. SOLANES CORELLA, "Contra la normalización de la ilegalidad: la protección judicial de los extranjeros frente a las expulsiones colectivas y las devoluciones en caliente", Cuadernos Electrónicos de Filosofía del Derecho (CEFD), número 36, 2017, pp. 195-225.

A. VOGEL, "La criminalización de la migración ilegal en Estados Unidos: el caso de la ley de Arizona (SB 1070) y su parcial inconstitucionalidad" en L. L. HIERRO (coord.), Autonomía individual frente a autonomía colectiva. Derechos en conflicto, Marcial Pons, Madrid, 2014, pp. 220-255.

C. C. WHITE, "Australia's Boatpeople Policy: Regional Cooperation or Passing the Buck?", Cultural Encounters, Conflicts, and Resolutions, Vol. 1, Iss. 1, Article 8, 2014, pp. 1-21, disponible en

https://engagedscholarship.csuohio.edu/cgi/viewcontent.cgi?art icle $=1006 \&$ context $=$ cecr (última consulta: 30 de enero de 2020).

C. PÉREZ GONZÁLEZ, "Límites a la lucha contra la inmigración irregular por vía marítima impuestos por el derecho internacional de los derechos humanos" en L. L. HIERRO 
(coord.), Autonomía individual frente a autonomía colectiva. Derechos en conflicto, Marcial Pons, Madrid, 2014, pp. 193-218.

C. SOLER GARCÍA, "La prohibición de las expulsiones colectivas de extranjeros en la jurisprudencia del Tribunal europeo de Derechos Humanos: especial referencia al caso de España", Revista General de Derecho Europeo, número 45, 2018, pp. 107-160.

C. WITHOL DE WENDEN, El fenómeno migratorio en el siglo XXI. Migrantes, refugiados y relaciones internacionales, trad. de G. Vallejo Cervantes, primera edición en español, Fondo de Cultura Económica, México, D.F., 2013.

¿Hay que abrir las fronteras?, trad. de J. M. Marcén, Bellaterra, Barcelona, 2000.

F. BARRERA LÓPEZ, La política de admisión de extranjeros inmigrantes en el derecho español y sus repercusiones éticopolíticas. Una expresión de la cultura del control y de la lógica del pragmatismo, Editorial de la Universidad de Granada, Granada, 2008.

F. VACAS FERNÁNDEZ, El Derecho Migratorio, Internacional y europeo, como Límite desde los Derechos Humanos a la Discrecionalidad de los Estados en Materia Migratoria, Tirant lo Blanch, Valencia, 2017.

Los tratados bilaterales adoptados por España para regular y ordenar los flujos migratorios. Contexto, marco jurídico y contenido, Dykinson, Madrid, 2007.

I. RUIZ-GIMENEZ ARRIETA, "Derechos Humanos: Género e Inmigración", en XXXVI Congreso de Teología, Migrantes, refugiados y fronteras. De la exclusión a la hospitalidad, Centro Evangelio y Liberación, 2016, pp. 19-36.

J. C. VELASCO, "Fronteras abiertas, derechos humanos y justicia global", Revista ARBOR: Ciencia, Pensamiento y Cultura, Volumen 188 (755), 2012, pp. 457-473.

J. DE LUCAS, "Negar la política, negar sus sujetos y derechos (Las políticas migratorias y de asilo como emblemas de la necropolítica)", Cuadernos Electrónicos de Filosofía del Derecho, número 36, 2017, pp. 64-87.

"La construcción de espacios anómicos para inmigrantes y refugiados. Sobre la creciente evolución de las políticas de la Unión Europea", Administración \& Cidadanía: Revista Da Escola Galega de Administración Pública, Volumen 11, número 1, 2016, pp. 179-191.

"Refugiados como "moneda de cambio". Sobre el acuerdo entre la Unión Europea y Turquía De 18 de marzo de 2016", Anuario de Derechos Humanos, número 12, 2016, pp. 17-32.

Mediterráneo: El naufragio de Europa, Tirant Humanidades, Valencia, 2015.

"Políticas migratorias sin libertad de circulación. La UE, en guerra frente a la inmigración y el asilo" en L. L. HIERRO 
(coord.), Autonomía individual frente a autonomía colectiva. Derechos en conflicto, Marcial Pons, Madrid, 2014, pp. 173-192. "Inmigrantes: del estado de excepción al estado de derecho", Oñati socio-legal series, Volumen 1, número 3, 2011, pp. 1-14. Puertas que se cierran. Europa como fortaleza, Icaria, Barcelona, 1996.

J. URBANEJA CILLÁN, "La declaración UE-Turquía, de 18 de marzo de 2016: ¿Un acuerdo de la Unión Europea? en N. CORNAGO, J. L. DE CASTRO y L. MOURE (eds.), Repensar la Unión Europea: Gobernanza, seguridad, mercado interior y ciudadanía. XXVII Jornadas AEPDIRI, Tirant lo Blanch, Valencia, 2019, pp. 323338.

M. D. BOLLO AROCENA, Expulsión de extranjeros, derecho internacional y derecho europeo, Thomson Reuters Aranzadi, Pamplona, 2016.

M. MARTÍNEZ ESCAMILLA, "Devoluciones en caliente. Un análisis jurídico" en J. L. VILLENA HIGUERAS (coord.), Derechos humanos y justicia universal en la frontera sur, Universidad de Granada, Granada, 2016, pp. 77-96.

N. ARENAS HIDALGO, "El acuerdo europeo de readmisión de inmigrantes en situación irregular con Pakistán. Punto de inflexión o huida hacia delante", Revista General de Derecho Europeo, número 24, 2011, pp. 1-40.

- "Los acuerdos europeos de readmisión de inmigrantes en situación irregular. Diez años de política europea de readmisión a debate", Cuadernos Europeos de Deusto, número 43, 2010, pp. 53-90.

N. DE GENOVA y N. PEUTZ, "Introduction" en N. DE GENOVA and N. PEUTZ (eds.), The deportation regime. Sovereignty, space, and the freedom of movement, Duke University Press, United States of America, 2010, pp. 1-29.

P. CERIANI CERNADAS, "Los derechos políticos de extranjeros en España desde un enfoque de derechos humanos: la ilegitimidad del principio de reciprocidad" en J. DE LUCAS y Á. SOLANES CORELLA (eds.), La igualdad en los derechos: claves de la integración, Dykinson, Madrid, 2009, pp. 481-519.

- $\quad$ "Los derechos de los migrantes sin residencia legal en la Jurisprudencia del TEDH: Un balance complejo ante la realidad y retos de la inmigración en la región" en P. CERIANI CERNADAS y R. FAVA (eds.), Políticas migratorias y derechos humanos, Ediciones UNLa, 2009, pp. 173-243.

S. BECERRIL, "Actuaciones de la Defensoría del Pueblo español en torno a los DDHH y la situación de la valla en Melilla" en J. L. Villena Higueras (coord.), Derechos humanos y justicia universal en la frontera sur, Universidad de Granada, Granada, 2016, pp. 61-76.

S. MEZZADRA y B. NEILSON, La frontera como método, trad. de V. Hendel, Traficantes de Sueños, Madrid, 2017. 
S. SASSEN, ¿Perdiendo el control? La soberanía en la era de la globalización, trad. de V. Pozanco, Bellaterra, Barcelona, 2001.

S. TORRECUADRADA GARCÍA-LOZANO, "Migraciones en masa en el derecho internacional" en N. CORNAGO, J. L. DE CASTRO y L. MOURE (eds.), Repensar la Unión Europea: Gobernanza, seguridad, mercado interior y ciudadanía. XXVII Jornadas AEPDIRI, Tirant lo Blanch, Valencia, 2019, pp. 135-151.

\section{2.- Informes, comentarios, observaciones de organismos internacionales de protección de los derechos humanos e informes de las organizaciones de la sociedad civil}

Agencia de la ONU para los Refugiados (ACNUR), Opinión Consultiva sobre la aplicación extraterritorial de las obligaciones de no devolución en virtud de la Convención sobre el Estatuto de los Refugiados de 1951 y su Protocolo de 1967, Ginebra, 26 de enero de 2007, disponible en https://www.acnur.org/fileadmin/Documentos/BDL/2009/7123. pdf (última consulta: 30 de enero de 2020).

Amnistía Internacional, El coste humano de la fortaleza europea. Violaciones de derechos humanos en las fronteras de Europa contra personas migrantes y refugiadas, 2014, disponible en https://www.amnesty.org/download/Documents/8000/eur0500 12014es.pdf (última consulta: 30 de enero de 2020).

Asamblea General de Naciones Unidas, Resolución aprobada por la Asamblea General el 20 de diciembre de 2012 [sobre la base del informe de la Tercera Comisión (A/67/457/Add.2 y Corr.1)] 67/172. Protección de los migrantes, 3 de abril de 2013, A/RES/67/172, disponible en https://undocs.org/es/A/RES/67/172 (última consulta: 30 de enero de 2020).

Comisión de Derecho Internacional, Asamblea General de Naciones Unidas, Informe de la Comisión de Derecho Internacional $66^{\circ}$ período de sesiones, 5 de mayo a 6 de junio y 7 de julio a 8 de agosto de 2014, A/69/10, Capítulo IV: Expulsión de extranjero, pár. E. Texto del proyecto de artículos sobre la expulsión de extranjeros, disponible

en https://www.refworld.org.es/pdfid/5915f0e84.pdf （última consulta: 30 de enero de 2020).

Comisión Española de Ayuda al Refugiado (CEAR), Informe 2016: Las personas refugiadas en España y Europa, disponible en https://www.cear.es/wp-

content/uploads/2016/06/Informe_CEAR_2016.pdf (última consulta: 30 de enero de 2020).

Comisión Interamericana de Derechos Humanos, Derechos humanos de los migrantes $y$ otras personas en el contexto de la movilidad humana en México, 30 de diciembre 2013, OEA/Ser.L/V/II. Doc. 48/13, disponible en 
http://www.oas.org/es/cidh/migrantes/docs/pdf/InformeMigrantes-Mexico-2013.pdf (última consulta: 30 de enero de 2020).

Comité contra la Tortura de Naciones Unidas, Convención contra la Tortura y Otros Tratos o Penas Crueles, Inhumanos o Degradantes. Observación general No 2, aplicación del artículo 2 por los Estados Partes, 24 de enero de 2008, CAT/C/GC/2, disponible en https://www.refworld.org.es/docid/5d7fcb5ea.html (última consulta: 30 de enero de 2020).

Comité contra la Tortura de Naciones Unidas, Observación general $N^{\circ}$ 4 (2017), relativa a la aplicación del artículo 3 de la Convención en el contexto del artículo 22, 4 de septiembre de 2018, CAT/C/GC/4, disponible en https://undocs.org/es/CAT/C/GC/4 (última consulta: 30 de enero de 2020).

Comité de Derechos Humanos de Naciones Unidas, Observación general $N^{\circ}$ 15: La situación de los extranjeros con arreglo al Pacto, 11 de abril de 1986, disponible en https://www.acnur.org/fileadmin/Documentos/BDL/2001/1403. pdf (última consulta: 30 de enero de 2020).

Comité de Derechos Humanos de Naciones Unidas, Observación general No 31 [80]: Naturaleza de la obligación jurídica general impuesta a los Estados Partes en el Pacto, 26 mayo 2004, CCPR/C/21/Rev.1/Add.13, disponible en https://www.refworld.org.es/docid/478b26ea2.html (última consulta: 30 de enero de 2020).

Consejo de Derechos Humanos de la Asamblea General de Naciones Unidas, Informe del Relator Especial sobre los derechos humanos de los migrantes, 4 de mayo de 2018, A/HRC/38/41, disponible en https://undocs.org/es/A/HRC/38/41 (última consulta: 30 de enero de 2020).

Consejo de Derechos Humanos de la Asamblea General de Naciones Unidas, Informe del Alto Comisionado de las Naciones Unidas para los Derechos Humanos sobre la situación de los derechos humanos en Libia y las necesidades conexas de asistencia técnica y fomento de la capacidad del país, 12 de enero de 2015, A/HRC/28/51, https://undocs.org/es/A/HRC/28/51 (última consulta: 30 de enero de 2020).

Consejo de Derechos Humanos de la Asamblea General de Naciones Unidas, Informe del Relator Especial sobre los derechos humanos de los migrantes, François Crépeau. Estudio regional: administración de las fronteras periféricas de la Unión Europea $y$ sus repercusiones sobre los derechos humanos de los migrantes, 24 de abril de 2013, A/HRC/23/46, disponible en https://www.acnur.org/fileadmin/Documentos/BDL/2014/9658. pdf?view=1 (última consulta: 30 de enero de 2020). 
Consejo de Derechos Humanos de la Asamblea General de Naciones Unidas, Promoción y protección de todos los derechos humanos, civiles, políticos, económicos, sociales y culturales, incluido el derecho al desarrollo. Informe del Relator Especial sobre los derechos humanos de los migrantes, Sr. Jorge Bustamante, 25 de febrero de 2008, A/HRC/7/12 disponible en https://undocs.org/es/A/HRC/7/12 (última consulta: 30 de enero de 2020).

Consejo de la Unión Europea, Consejo Europeo de Sevilla, 21 y 22 de junio. Conclusiones de la presidencia, 24 de octubre de 2002, 13463/02, disponible en https://www.consilium.europa.eu/media/20922/72639.pdf (última consulta: 30 de enero de 2020).

Corte Interamericana de Derechos Humanos, Opinión Consultiva OC18/03 "Condición Jurídica y Derechos de los Migrantes Indocumentados", 17 de septiembre de 2003, disponible en http://www.corteidh.or.cr/docs/opiniones/seriea_18_esp.pdf (última consulta: 30 de enero de 2020).

International Organization for Migration (IOM), Missing migrants. Tracking deaths along migratory routes, disponible en https://missingmigrants.iom.int/about (última consulta: 30 de enero de 2020).

Oficina del Alto Comisionado de Naciones Unidas para los Derechos humanos (ACNUDH), Migración y derechos humanos. Mejoramiento de la gobernanza basada en los derechos humanos de la migración internacional, 2013, disponible en https://www.ohchr.org/Documents/Issues/Migration/MigrationH R_improvingHR_ReporSPt.pdf (última consulta: 30 de enero de 2020).

Rapport explicati du Protocole núm. 4 à la Convention de sauvegarde des Droits de l'Homme et des Libertés fondamentales, reconnaissant certains droits et libertés autres que ceux figurant déjà dans la Convention et dans le premier Protocole additionnel à la Convention, Estrasburgo, 16 de diciembre de 1963, disponible en https://rm.coe.int/16800c9330 (última consulta: 30 de enero de 2020).

ReSOMA - Research Social Plataform on Migration and Asylum, Crackdown on NGOs and volunteers helping refugees and other migrants, disponible en http://www.resoma.eu/sites/resoma/resoma/files/policy_brief/p df/Final\%20Synthetic\%20Report\%20-

\%20Crackdown\%20on\%20NGOs\%20and\%20volunteers\%20hel ping\%20refugees\%20and\%20other\%20migrants_1.pdf (última consulta: 30 de enero de 2020). 


\section{3.- Textos normativos y jurisprudencia}

Acuerdo de Schengen - Convenio de aplicación del Acuerdo de Schengen de 14 de junio de 1985 entre los Gobiernos de los Estados de la Unión Económica Benelux, de la República Federal de Alemania y de la República Francesa relativo a la supresión gradual de los controles en las fronteras comunes, 22 de septiembre de 2000, disponible en https://eurlex.europa.eu/legalcontent/ES/ALL/?uri=CELEX\%3A42000A0922\%2802\%29

(última consulta: 30 de enero de 2020).

Carta Africana sobre Derechos Humanos y de los Pueblos, 27 de julio de 1981, disponible en http://www.derechoshumanos.net/normativa/normas/africa/CA FDH/1981-CAFDH.htm (última consulta: 30 de enero de 2020).

Carta Árabe de Derechos Humanos, 22 de mayo de 2004, disponible en https://www.right-to-education.org/sites/right-toeducation.org/files/resourceattachments/Revised_Arab_Charter_Human_Rights_2004_Em.p df (última consulta: 30 de enero de 2020).

Carta de los Derechos Fundamentales de la Unión Europea, 30 marzo de 2010, (2010/C 83/02), disponible en https://www.boe.es/doue/2010/083/Z00389-00403.pdf (última consulta: 30 de enero de 2020).

Carta Social Europea, adoptado por el Consejo de Europa el 18 de octubre de 1961, Turín, disponible en https://www.boe.es/buscar/act.php?id=BOE-A-1980-13567

(última consulta: 30 de enero de 2020).

Convención Americana sobre Derechos Humanos (Pacto de San José), 22 de noviembre de 1969, disponible en https://www.oas.org/dil/esp/tratados_b-

32_convencion_americana_sobre_derechos_humanos.htm

(última consulta: 30 de enero de 2020).

Convención contra la Tortura y Otros Tratos o Penas Crueles, Inhumanos o Degradantes, adoptada y abierta a la firma, ratificación y adhesión por la Asamblea General en su resolución 39/46, de 10 de diciembre de 1984, entrada en vigor: 26 de junio de 1987, disponible en https://www.ohchr.org/sp/professionalinterest/pages/cat.aspx (última consulta: 30 de enero de 2020).

Convención Internacional sobre la Protección de los Derechos de Todos los Trabajadores Migratorios y de sus Familiares, adoptada por la Asamblea General en su resolución 45/158, de 18 de diciembre de 1990, disponible en https://www.ohchr.org/sp/professionalinterest/pages/cmw.aspx (última consulta: 30 de enero de 2020).

Convención Internacional para la Protección de Todas las Personas contra las Desapariciones Forzadas, adoptada por la Asamblea 
General de Naciones Unidas en su resolución A/RES/61/177 del 20 de diciembre de 2006, disponible https://undocs.org/es/A/RES/61/177 (última consulta: 30 de enero de 2020).

Convención sobre el Estatuto de los Refugiados, adoptada por la Conferencia de Plenipotenciarios sobre el Estatuto de los Refugiados y de los Apátridas (Naciones Unidas), convocada por la Asamblea General en su resolución 429 (V), el 28 de julio de 1951 en Ginebra, Suiza, disponible en https://www.acnur.org/5b0766944.pdf (última consulta: 30 de enero de 2020).

Convenio Europeo para la Protección de los Derechos Humanos y de las Libertades Fundamentales, adoptado por el Consejo de Europa el 4 de noviembre de 1950, entrada en vigor 1953, disponible en https://www.echr.coe.int/Documents/Convention_SPA.pdf (última consulta: 30 de enero de 2020).

Declaración Universal de Derechos Humanos, proclamada por la Asamblea General de las Naciones Unidas en su resolución 217 A (III), el 10 de diciembre de 1948 en París, disponible en https://www.un.org/es/universal-declaration-human-rights/ (última consulta: 30 de enero de 2020).

Directiva 2001/51/CE del Consejo, de 28 de junio de 2001, por la que se completan las disposiciones del artículo 26 del Convenio de aplicación del Acuerdo de Schengen de 14 de junio de 1985, disponible en https://www.boe.es/doue/2001/187/L0004500046.pdf (última consulta: 30 de enero de 2020).

Directiva 2002/90/CE del Consejo, de 28 de noviembre de 2002, destinada a definir la ayuda a la entrada, a la circulación y a la estancia irregular, disponible en https://www.boe.es/doue/2002/328/L00017-00018.pdf (última consulta: 30 de enero de 2020).

Directiva 2004/82/CE del Consejo, de 29 de abril de 2004, sobre la obligación de los transportistas de comunicar los datos de las personas transportadas, disponible en https://www.boe.es/doue/2004/261/L00024-00027.pdf (última consulta: 30 de enero de 2020).

Directiva 2008/115/CE del Parlamento Europeo y del Consejo, de 16 de diciembre de 2008, relativa a normas y procedimientos en los Estados miembros para el retorno de los nacionales de terceros países en situación irregular, disponible en https://eurlex.europa.eu/legalcontent/ES/TXT/?uri=CELEX\%3A32008L0115 (última consulta: 30 de enero de 2020).

Directiva 2013/32/UE del Parlamento Europeo y del Consejo, de 26 de junio de 2013, sobre procedimientos comunes para la concesión o la retirada de la protección internacional, disponible en https://eur-lex.europa.eu/legal- 
content/es/TXT/?uri=celex:32013L0032 (última consulta: 30 de enero de 2020).

Entrada en vigor del Acuerdo entre el Reino de España y el Reino de Marruecos relativo a la circulación de personas, el tránsito y la readmisión de extranjeros entrados ilegalmente, hecho en Madrid el 13 de febrero, de 13 de diciembre de 2012 (BOE 299 de diciembre de 2012), disponible en https://www.boe.es/diario_boe/txt.php?id=BOE-A-2012-15050 (última consulta: 30 de enero de 2020).

Acuerdo entre el Reino de España y el Reino de Marruecos relativo a la circulación de personas, el tránsito y la readmisión de extranjeros entrados ilegalmente, firmado en Madrid el 13 de febrero de 1992, de 25 de abril de 1992 (BOE 100 de abril de 1992), disponible en https://www.boe.es/diario_boe/txt.php?id=BOE-A-1992-8976 (última consulta: 30 de enero de 2020).

Ley Orgánica 4/2000, de 11 de enero, sobre derechos y libertades de los extranjeros en España y su integración social (BOE 10 de enero de 2000), en https://www.boe.es/buscar/doc.php?id=BOE-A-2000-544

(última consulta: 30 de enero de 2020).

Ley Orgánica 4/2015, de 30 de marzo, de protección de la seguridad ciudadana (BOE 77 de marzo de 2015), disponible en https://boe.es/buscar/doc.php?id=BOE-A-2015-3442 (última consulta: 30 de enero de 2020).

Pacto Internacional de Derechos Civiles y Políticos, adoptado por la Asamblea General de Naciones Unidas en su resolución 2200 A (XXI) de 16 de diciembre de 1966, disponible en https://www.ohchr.org/sp/professionalinterest/pages/ccpr.aspx (última consulta: 30 de enero de 2020).

Protocolo contra el tráfico ilícito de migrantes por tierra, mar y aire, que complementa la Convención de las Naciones Unidas contra la Delincuencia Organizada Transnacional, adoptado por la Asamblea General de Naciones Unidas en su resolución 55/25 de 15 de noviembre de 2000, disponible en https://www.unodc.org/documents/treaties/UNTOC/Publications /TOC\%20Convention/TOCebook-s.pdf (última consulta: 30 de enero de 2020).

Protocolo $n^{\circ} 4$ al Convenio para la Protección de los Derechos Humanos y de las Libertades Fundamentales que reconoce ciertos derechos y libertades además de los que ya figuran en el Convenio y en el primer Protocolo adicional al Convenio, modificado por el Protocolo $n^{\circ} 11$, adoptado por el Consejo de Europa el 16 de septiembre de 1963, entrada en vigor 1968, disponible en https://www.echr.coe.int/Documents/Convention_SPA.pdf (última consulta: 30 de enero de 2020). 
Protocolo $n^{\circ} 7$ al Convenio para la Protección de los Derechos Humanos y de las Libertades Fundamentales, adoptado por el Consejo de Europa el 22 de noviembre de 1984, disponible en https://www.echr.coe.int/Documents/Convention_SPA.pdf (última consulta: 30 de enero de 2020).

Protocolo para prevenir, reprimir y sancionar la trata de personas, especialmente mujeres y niños que complementa la Convención de las Naciones Unidas contra la Delincuencia Organizada Transnacional, adoptado por la Asamblea General de Naciones Unidas en su resolución 55/25 de 15 de noviembre de 2000, disponible en https://www.unodc.org/documents/treaties/UNTOC/Publications /TOC\%20Convention/TOCebook-s.pdf (última consulta: 30 de enero de 2020).

Reglamento (CE) 2007/2004 del Consejo, de 26 de octubre de 2004, por el que se crea una Agencia Europea para la gestión de la cooperación operativa en las fronteras exteriores de los Estados miembros de la Unión Europea, disponible en https://eurlex.europa.eu/legal-

content/ES/ALL/?uri=CELEX\%3A32004R2007 (última consulta: 30 de enero de 2020).

Reglamento (UE) 604/2013 del Parlamento Europeo y del Consejo, de 26 de junio de 2013 por el que se establecen los criterios y mecanismos de determinación del Estado miembro responsable del examen de una solicitud de asilo presentada en uno de los estados miembros por un nacional de un tercer país o un apátrida (texto refundido), disponible en https://eurlex.europa.eu/legal-

content/ES/TXT/?uri=CELEX\%3A32013R0604 (última consulta: 30 de enero de 2020).

TEDH, Hirsi Jamaa y otros contra Italia, de 23 de febrero de 2012, en la demanda $n^{\circ}$ 27765/09, disponible en http://hudoc.echr.coe.int/eng?i=001-139041 (última consulta: 30 de enero de 2020).

TEDH, N. D. y N. T. contra España, de 3 de octubre de 2017, en las demandas $n^{\circ} 8675 / 15$ y 8697/15, expulsión colectiva, disponible en https://www.refworld.org.es/docid/5a04a4da4.htmlm (última consulta: 30 de enero de 2020).

TEDH, Rantsev contra Chipre y Rusia, del 7 de enero de 2010, en la demanda $n^{\circ}$ 25965/04, disponible en http://hudoc.echr.coe.int/eng?i=001-139059 (última consulta: 30 de enero de 2020).

Versión consolidada del Tratado de Funcionamiento de la Unión Europea, 26 de octubre de 2012, (2012/C 326/01), disponible en https://eur-lex.europa.eu/legalcontent/es/ALL/?uri=CELEX\%3A12012E\%2FTXT 


\section{4.- Noticias}

eldiario.es, Marruecos archiva la causa contra la activista española Helena Maleno por sus Ilamadas a Salvamento Marítimo, 13 de marzo de 2019, disponible en https://www.eldiario.es/desalambre/Marruecos-activistaespanola-Helena-Maleno_0_876312784.html (última consulta: 30 de enero de 2020).

Europapress, Ban reclama a la UE medidas "para salvar vidas" en el Mediterráneo, 27 de mayo de 2015, disponible en https://www.europapress.es/internacional/noticia-ban-reclamaue-medidas-salvar-vidas-mediterraneo-20150527161023.html (última consulta: 30 de enero de 2020) 